Benito, G., Macklin, M. G., Zielhofer, C., Jones, A. F., and Machado, M. J., 2015,

Holocene flooding and climate change in the Mediterranean. Catena 130, 13-33.

\title{
Holocene flooding and climate change in the Mediterranean
}

\section{Gerardo Benito $^{\mathrm{a}^{*}}$, Mark G. Macklin ${ }^{\mathrm{b}, \mathrm{c}}$, Christoph Zielhofer ${ }^{\mathrm{d}}$, Anna F. Jones ${ }^{\mathrm{e}}$ and Maria J. Machado ${ }^{a}$}

${ }^{a}$ Museo Nacional de Ciencias Naturales, CSIC, Serrano 115 bis, 28006 Madrid, Spain.

${ }^{\mathrm{b}}$ Centre for Catchment and Coastal Research and the River Basin Dynamics and Hydrology Research Group, Department of Geography and Earth Sciences, Aberystwyth University, Ceredigion SY23 3DB, UK

${ }^{\mathrm{c}}$ Innovative River Solutions, Institute of Agriculture and Environment, Massey

University, Private Bag 11 222, Palmerston North, 4442, New Zealand

d Institute of Geography, Leipzig University, Johannisallee 19a, 04103 Leipzig, Germany

${ }^{\mathrm{e}}$ School of Geography, Planning and Environmental Policy, University College Dublin, Newman Building, Belfield, Dublin 4, Ireland

\section{*Corresponding author: benito@mncn.csic.es}

Key words: Palaeofloods, Palaeohydrology, Holocene, extreme events, climate change, Mediterranean

\begin{abstract}
Mediterranean fluvial hydrology is characterised by decadal-to-multi-centennial length wet and dry episodes with abrupt transitions related to changes in atmospheric circulation. Since the mid-1990s site-based flood chronologies from slackwater deposits in bedrock rivers and regionally aggregated flood histories from alluvial deposits have developed increasingly higher resolution chronological frameworks, although regional coverage is still uneven. This paper analyses the spatial and temporal distribution of extreme Holocene hydrological events recorded in fluvial stratigraphy in the Iberian Peninsula (Spain and Portugal), southern France, southern Italy, Northern Africa (Morocco and Tunisia) and eastern Mediterranean (Greece, Crete, Turkey, Cyprus and Israel). This study constitutes the most comprehensive investigation of Holocene river flooding ever undertaken in the Mediterranean and is based on the analysis of $515{ }^{14} \mathrm{C}$ and 53 OSL dates. It reveals that flood periods in different regions cluster into distinct time intervals, although region-wide flooding episodes can be identified at 7400-7150, 4800-4600, 4100-3700, 3300-3200, 2850-2750, 2300-2100, 1700-1600, 1500-1400, 950-800, ca. 300, 200-100 cal. BP. Periods with more frequent floods in the western Iberian region coincide with transitions to cool and wetter conditions and persistent negative NAO mode. In Northern Africa increased flood frequency coincides with periods of generally drier climate, while in the eastern Mediterranean there is a higher incidence of extreme flood events under wetter conditions. Our meta-data analysis identifies an out-of-phase pattern of extreme events across the Mediterranean over multi-centennial timescales, which is particularly evident between the western Iberian and eastern Mediterranean regions. This centennial-to-multi-centennial see-saw pattern in flooding indicates that bipolar hydroclimatic conditions existed in the Mediterranean during the Holocene.
\end{abstract}




\section{Introduction}

Mediterranean river hydrology is strongly influenced by the seasonal distribution of the precipitation (Thornes et al., 2009). River flow regime in the region is characterised by maximum discharge during the autumn and winter months, minimum discharge in summer, as well as by extreme seasonal and annual discharge variability with peak discharges frequently more than 50 times average flows (Pardé, 1950). Past hydrological records from instrumental, documentary and fluvial sedimentary archive sources also show significant hydroclimatic variability with multi-decadal to multicentennial length alternation of wet and dry episodes with abrupt transitions related to changes in atmospheric circulation (Macklin et al., 1995; Benito, 2003; Macklin and Woodward, 2009; Zielhofer et al. 2010, Fletcher and Zielhofer 2013). As a result, extreme hydrological events are an inherent component of past and present Mediterranean hydrology whose controlling climatic mechanisms are difficult to predict and model.

Societal response to this high hydrological variability on water resources in the region is reflected in the early construction of reservoirs and irrigation schemes beginning in Roman times that became ubiquitous during the Middle Ages, although construction of large scale arch dams did not occur until the late $18^{\text {th }}$ century (Butzer et al., 1983; 1985). Written records of hydrological events, mostly related to the impacts of severe floods and droughts, started as early as the $13^{\text {th }}$ century (Barriendos Vallve and Martín-Vide, 1998; Brázdil et al., 2012). Centennial to millennial-length records have also been retrieved from sedimentary records which can be combined with historical documentary evidence (e.g. Benito et al., 2010). Both, sedimentary and documentary archives record an alternation of flood-rich and flood-poor periods over the Holocene (Thorndycraft and Benito, 2006b; Macklin and Woodward, 2009). Hence, a pan-Mediterranean analysis of the timing of those periods may provide further information concerning the driving mechanisms (climate and/or environmental changes related to human impact) enhancing or reducing the occurrence of extreme events.

Extensive use of radiometric dating in the study of Holocene fluvial archives has much improved the records of extreme hydrological events worldwide, and presents the opportunity to compare the occurrence of extreme hydrological events at regional and inter-regional scales (Macklin et al., 2006; Macklin et al., 2012). An extreme hydrological event is here defined, following Gregory et al. (2006), as any past process or phenomenon related to the hydrological cycle (e.g. rainfall, runoff, snowmelt, flood, water recharge) with a magnitude significantly higher or lower than the mean and very often associated with crossing a geomorphic threshold. A hydrological event may relate to periods ranging from minutes to months (e.g. floods), or up to several years in the case of droughts. Clustering of extreme hydrological events has been related to climate variability (Rumsby and Macklin, 1994; Ely, 1997; Knox, 2000; Redmond et al., 2002), although land use changes have affected runoff generation at the catchment scale, 
particularly during the Middle Ages and the 19th Century (Greenbaum et al., 2006; Benito et al., 2010).

Recent fluvial research in the Mediterranean has focused on trying to extend flood series primarily as a means of identifying changes in the frequency and magnitude of floods and relating these to atmospheric circulation patterns modulated by climate variability (Macklin et al., 2006; Thorndycraft and Benito, 2006a; Macklin et al., 2010; Luterbacher et al., 2012; Fletcher and Zielhofer, 2013). Both site-based flood chronologies (Benito et al., 2003a; Benvenuti et al., 2006; Greenbaum et al., 2006) and regionally aggregated flood histories (Zielhofer and Faust, 2008; Arnaud-Fassetta et al., 2010) have developed increasingly higher resolution chronological frameworks based on meta-analysis of large radiocarbon-dated fluvial databases. Following the approach developed by Macklin and Lewin (2003), systematic and probability-based analysis of radiocarbon dated fluvial units from a growing number of Mediterranean regions has recently been undertaken, facilitated through the analysis of different sub-sets of radiocarbon dates classified by depositional environment and catchment physiography (Macklin et al., 2006; Thorndycraft and Benito, 2006a,b; Zielhofer and Faust, 2008; Benito et al., 2008). This paper aims to evaluate large databases of ${ }^{14} \mathrm{C}$ - and OSL-dated Holocene fluvial units in different regions across the Mediterranean in order to identify past extreme hydrological events, their temporal and geographical distribution, and possible relationships with climate variability and land-use change.

\section{Hydroclimatology of the Mediterranean region}

The Mediterranean region lies between $30-47^{\circ} \mathrm{N}$ and $10^{\circ} \mathrm{W}$ and $35^{\circ} \mathrm{E}$ (Fig. 1), and is a zone of transition between the continental influences of Europe, Asia, and the northAfrican desert, and the maritime effects of the Atlantic Ocean and Mediterranean Sea (Harding et al., 2009). The seasonal and interannual climate of the northern and western parts of the region is linked to the mid-latitude atmospheric patterns characterised by the NAO (North Atlantic Oscillation) and other mid-latitude teleconnection patterns such as the Arctic Oscillation (Xoplaki et al., 2004; Lionello and Galati, 2008). The southeast Mediterranean region is under the subtropical influence of the descending branch of the Hadley cell for a large part of the year and is exposed to the Asian monsoon in summer and to the western Russian/Siberian High Pressure System in winter (Corte-Real et al., 1995; Xoplaki et al., 2004; Lionello et al., 2006). The climate of the Mediterranean exhibits strong contrasts between different areas due to its complex orography and its location within the boundary between subtropical and mid-latitude atmospheric patterns (Lionello et al., 2006; Trigo et al., 2006). Temperature and precipitation contrasts are significant, with permanent glaciers in the humid northern alpine area, subtropical desert areas at the North African coast, temperate marine climate in north-west Iberia and steppe and semiarid conditions in the Levant. The lack of rainfall during summer is the defining characteristic of the Mediterranean regions. In summer, the western Mediterranean (Iberia, France, 
Morocco, Italy) is mainly under the influence of the Azores subtropical high, whereas the eastern part (Greece, Cyprus, Crete, Turkey, Israel) falls under a low pressure area extending from the Persian Gulf northwest towards the eastern Mediterranean basin, associated with the Indian summer monsoon (Gat and Magaritz, 1980, Wigley and Farmer, 1982).
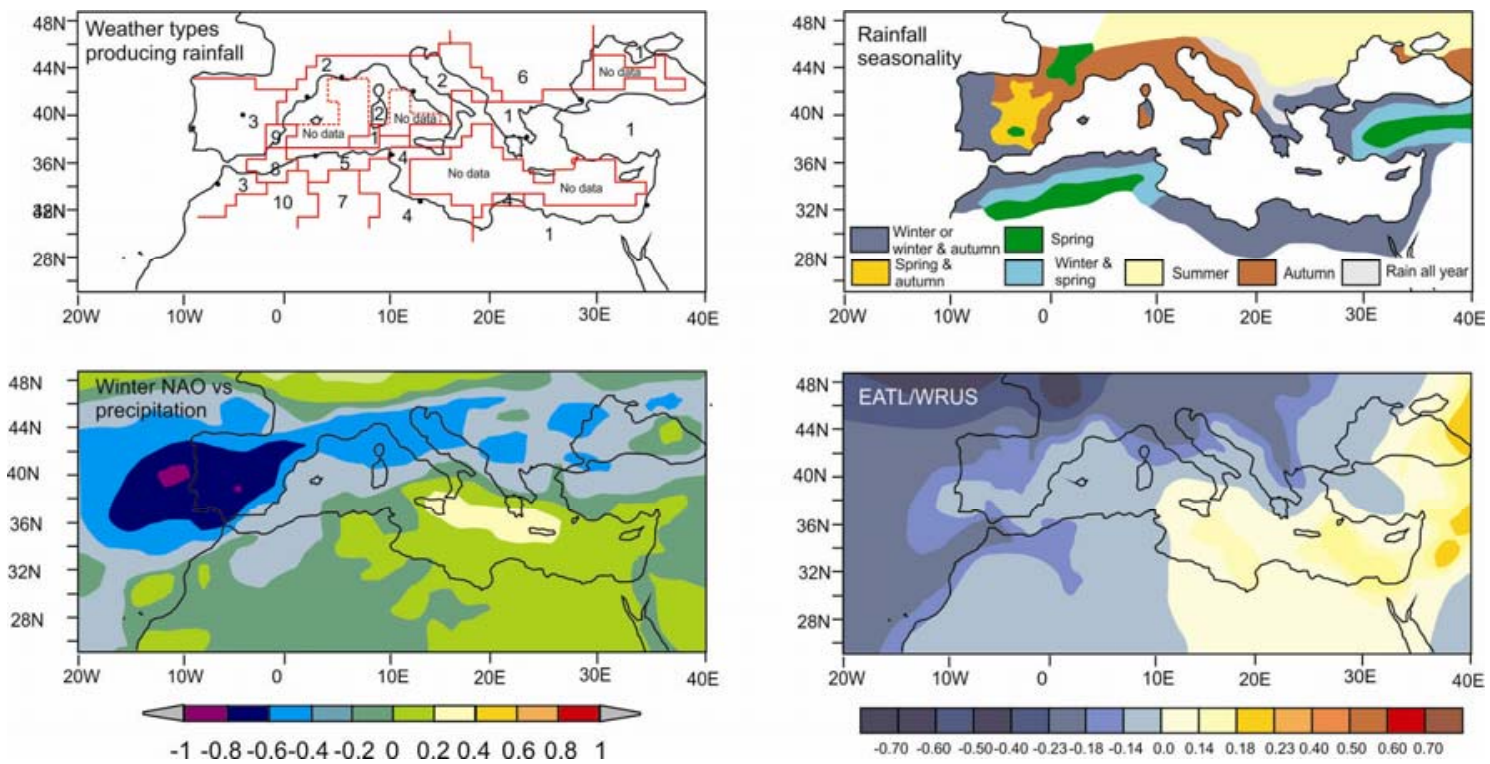

Figure 1. A: Mediterranean rainfall regions based on PCA analysis of weather types from daily occurrences of surface pressure centres at 500hPa (1992-1996) (Littmann, 2000). Numbers explained below. B: Rainfall regimes in the Mediterranean with indication of seasonal rainfall maxima (after Thornes et al., 2009). C: Correlation between NAO index and Mediterranean precipitation in the cold season (December-February), derived from the CRU NAO index and the NCEP reanalysis (Zorita et al., 2004). C: Spatial Spearman correlation between the East Atlantic/Western Russia patterns (EA/WRUS; Xoplaki et al., 2004) and winter (NDJF) Mediterranean precipitation for the period 1950-1999 (Xoplaki, 2002). Legend for weather types (A): 1.- November (max rainfall) to March. Linked to deflection of cyclonic tracks and Tyrrhenian cut-off flow towards Greece and Cyprus after the establishment of Siberian Anticyclone. 2.- September (maximum rainfall) until April with summer rainfall. Atlantic frontal systems explains $54 \%$ of rainfall from September to November. 3.- October to January related to Atlantic frontal systems. Second rainfall maximum in May. 4.- Drier than 3 with maximum rainfall occurring in October, December and February. 5.- Rainfall pattern similar to 2 but rainy season is shorter. 6.- Rainfall in all seasons but high amounts in winter (November, December) and summer (May, June). 7.- Short rainy season with rainfall above average in March and September. 8.- Moulouya basin. Rainfall from November to March and Maxima in February and March. 9.- Rainfall pattern similar to 2, but with a shorter season. 10.- Rainfall pattern similar to 2 but rainy season is shorter.

In terms of total annual rainfall, the Mediterranean region spans a wide range from arid $(<200 \mathrm{~mm})$ to humid (>3500 $\mathrm{mm}$, e.g. Montenegro), depending on location and orographic characteristics. Rainfall period duration may last only 2-3 months in some regions of North Africa and south-east Spain or it may cover autumn through to spring in France, northern Italy and the Balkan region. In winter, the negative mode of the NAO index produces a higher frequency of low pressure conditions associated with the invasion of maritime polar air masses leading to rains and wet conditions mainly in the Iberian Peninsula (Trigo et al., 2004; Fig. 1). In contrast, precipitation and atmospheric pressure in the eastern Mediterranean have been shown to have an anti-phase 
relationship with those found in the western Mediterranean (Xoplaki et al., 2004; Roberts et al., 2012). Wintertime in the eastern Mediterranean is affected by the Siberian High and associated polar continental air masses. A strong Siberian High favours southward excursions of the polar front jet that, modified by the land-sea temperature contrast, favours cyclogenesis and winter rains in the central and eastern parts of the Mediterranean basin (Wigley and Farmer, 1982). During autumn, as the westerlies extend southwards, there is an increase in westerly, north-westerly and southwesterly circulation types. In the western Mediterranean south-westerly circulation types are more frequent in late autumn, corresponding to an increase in blocking circulation and the subsequent genesis of cold pools, which sometimes produce catastrophic flooding in eastern Spain, southern France and Italy (Llasat and Puigcerver, 1990). During spring, as well as in late winter, there is a change in the main flow type with increasing southerly and south-westerly flows due to undulating circulation patterns, responsible for high precipitation in Morocco, Algeria, eastern and southeast Spain, and southern Italy (Harding et al., 2009).

Analysis of inter-annual precipitation trends shows an inverse correlation between the eastern and the western Mediterranean during the past hundred years (Conte et al., 1989). Conte et al. (1989) also suggested the existence of a Mediterranean Oscillation (MO) as a consequence of the see-saw pattern in atmospheric pressure and precipitation between the western and eastern Mediterranean that according to Roberts et al. (2012) has operated for at least the last 1000 years.

Mediterranean rivers have a wide variety of flooding regimes and seasonal discharge distributions, related to seasonal climatic characteristics (Thornes et al., 2009). High river flows occur between September and May with single or double maxima, usually in spring and autumn (Struglia et al., 2004). Maximum rainfall amounts (Fig. 1) occur during: (1) September and October in north-east and eastern Spain, south-east France and central-north Italy; (2) November in Sardinia, Liguria (north-west Italy), Andalusia (southern Spain), western Anatolia (Turkey), northern and central Greece, Albania, and Montenegro; (3) December in north-west Africa and Sicily; and (4) in January in Israel and Lebanon, Roussillon region (south-east France) and Noire Montagne (central France). Double discharge maxima following the equinoxes are related to the influence of high pressure over Mediterranean regions during January and February (e.g. Arno river, Italy), or by snow accumulation in the mountains during the winter months. Hydrological regimes of rivers draining high mountain areas (Atlas, Pyrenees, Alps, Dinaric Alps, Pindus and Taurus mountains) are dominated by snowmelt floods and by summer evapotranspiration, although high intensity rainfall may occur during summer (Beckinsale, 1969). In these mountain regions, the hydrological regime is moderate pluvio-nival or nivo-pluvial spring maximum (March to May), followed by low water in August or September. In the circum-Mediterranean region, low latitude rivers (below 
$35^{\circ} \mathrm{N}$ ) may frequently dry out during the summer months even in drainage basins larger than $1000 \mathrm{~km}^{2}$ (Pardé, 1950, Struglia et al., 2004)

\section{Fluvial environments and methodology}

In Mediterranean fluvial systems five types of sedimentary flood records have been studied: (i) overbank floodplain deposits (Zielhofer et al., 2008); (ii) flood-basin environments (Sancho et al., 2008); (iii) river channel gravels (Schulte, 2002); (iv) mountain torrent deposits - debris flows and boulder berms - (Maas and Macklin, 2002); and (v) slackwater flood sediments (Benito et al., 2003a). Alluvial river cut-andfill sequences, which typically preserve channel, floodplain and flood-basin deposits, record changes in the discharge-sediment load relationships that usually occur over periods of decades to centuries. Slackwater and boulder berm deposits, more commonly found in bedrock systems, can provide records of individual flood events that can sometimes be dated to within a decade or less (Maas and Macklin, 2002; Thorndycraft and Benito 2006; Macklin et al., 2010).

The long-term analysis of extreme hydrological events in Mediterranean alluvial records started in a systematic way in the 1990s, and focused on improving the chronological resolution of flood records based on dating and analysis of slackwater flood deposits (Benito et al., 1998; Greenbaum et al., 2000), sequences of fine-grained sediments deposited on floodplain environments indicative of high stage flows (López-Avilés et al., 1998; Zielhofer et al. 2002, Faust et al. 2004), and boulder berm deposits (Maas and Macklin, 2002). Flood frequency patterns have been related to shifts in atmospheric circulation patterns (Macklin et al, 2006; Thorndycraft and Benito, 2006a,b; Zielhofer et al. 2010), including the NAO (Maas and Macklin, 2002; Benito et al., 2008). Site-based flood chronologies have been reconstructed, combining sedimentary and documentary evidence of large floods (e.g. Benito et al., 2003a,b). Several approaches have also used regionally aggregated flood chronologies based on meta-analysis of large radiocarbonand OSL-dated Holocene fluvial databases (Macklin et al., 2006). Systematic and probability-based analysis based on radiocarbon dated fluvial deposits from a growing number of Mediterranean regions has recently been undertaken (Thorndycraft and Benito 2006a,b; Benito et al., 2008, Zielhofer and Faust, 2008; Piccarreta et al., 2011; Luterbacher et al., 2012), facilitated through the analysis of different sub-sets of radiocarbon dates, and the classification of flood units by depositional environment and catchment physiography. Each radiocarbon age sub-set is processed using radiocarbon calibration software, such as OxCal (Bronk Ramsey, 2008) to produce a cumulative probability density function (CPDF). Episodes of increased flooding are identified where relative probability exceeds mean relative probability and there is a minimum of three dated samples in two centuries. A detailed description of the process followed in the analysis and interpretation of Holocene fluvial chronologies based on the CPDF method can be found in Jones et al. (this volume). The analysed subsets only include dates within sediments indicative of a major flood event (e.g. slackwater flood deposits, 
floodplain deposits, paleochannel fills) or associated with abrupt modification of sedimentation rate or style (termed 'change' dates). In the database each recorded alluvial deposit is represented by a single radiocarbon age and when two or more dates are available from the same unit the age with the smallest error term is selected (Jones et al., this volume). Radiocarbon dates from archaeological sites on floodplains were not considered in the analysis, in order to avoid introducing bias towards periods relating to floodplain settlement (cf. Macklin and Lewin, 2003).

\section{Regional fluvial sedimentary records of extreme hydrological events}

In the following sections the results of the probability analyses are presented on a regional basis to evaluate changes in the spatial and temporal distribution of floods in the Mediterranean as a whole over the Holocene. The metadata have been divided into regional sub-sets on the basis of geographic location, hydroclimatic conditions and number of radiometric ages from fluvial archives.

\subsection{North-western Mediterranean region}

The analysis of the north-western Mediterranean region has been divided into three subsets: the Iberian Peninsula (Spain and Portugal), southern France (lower Rhône River and tributaries, and southern Alps rivers) and southern Italy (Fig. 2; Table 1). In general, the fluvial chronology of extreme hydrological events during the early to middle Holocene is limited due to the low preservation of deposits of this age in Mediterranean rivers with torrential regimes (Benito et al., 2008).

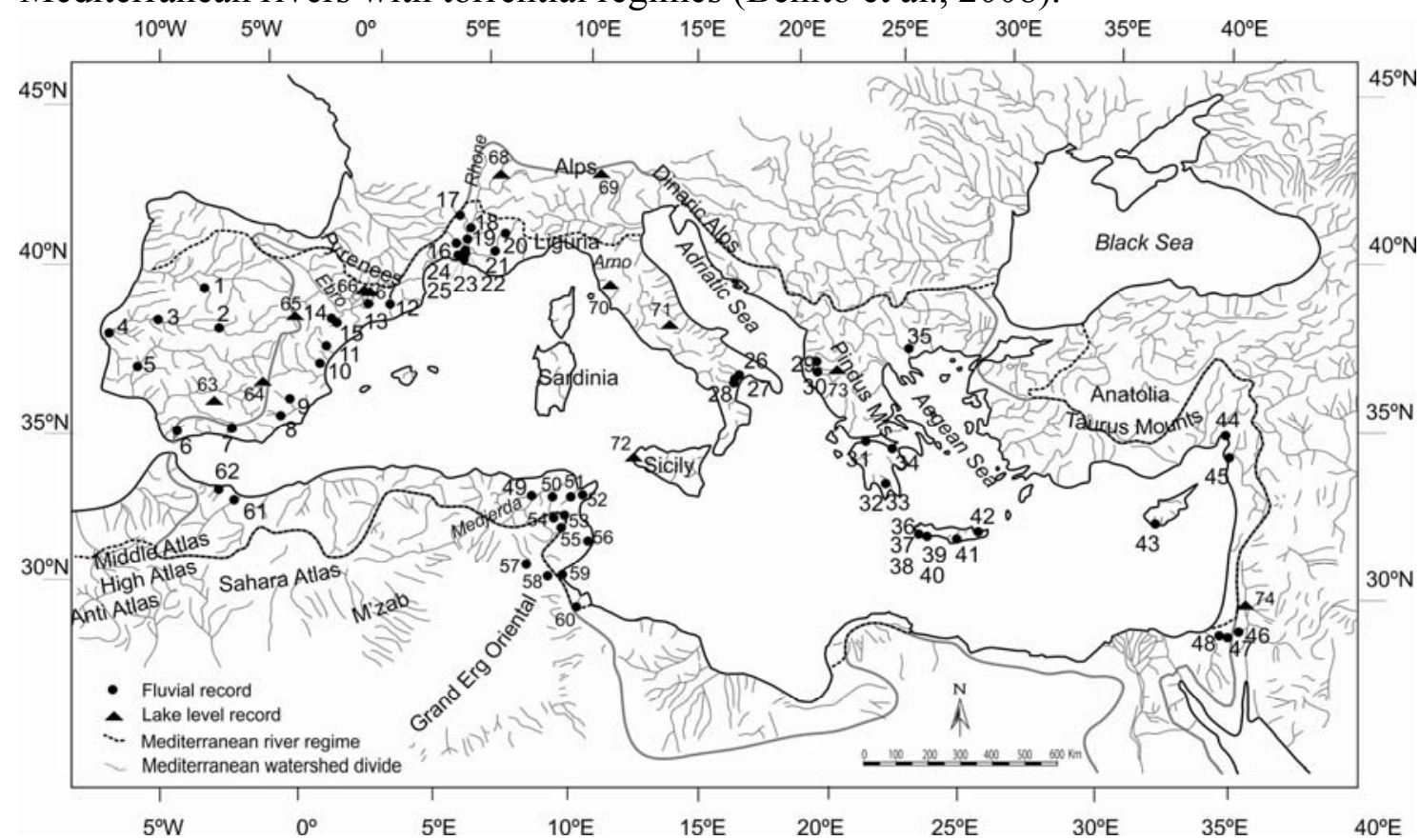

Figure 2. Major rivers and streams of the Mediterranean region and watershed of catchments draining into the Mediterranean Sea. Dots indicate the location of ${ }^{14} \mathrm{C}$ and OSL sample sites included in the analysis. Numbers refer to of sites cited in Table 1 and described in the text. 
In the Iberian Peninsula the summed probability distribution is composed of 123 radiocarbon dates from slackwater flood deposits, of which 86 dated units correspond to western Iberian rivers draining towards the Atlantic Ocean (Fig. 3, black line), and 37 dated units from eastern Iberian rivers flowing to the Mediterranean Sea (Fig. 3; grey shaded area). Radiocarbon dates are plotted (Fig. 3) as midpoint ages (in calibrated years BP) with the two sigma age range (95\%). Flood clusters obtained from palaeoflood sediments of Mediterranean and Atlantic rivers generally overlap in time despite differences in the synoptic conditions that generate floods in these two regions (Table 2). Slackwater flood deposits can be divided into six age clusters at 9500-9200; 4800-4500; 2850-2250; 1100-800; and 500-150 cal. BP (Table 2). This decadal to centennial-scale flood synchrony is believed to be the result of a predominance of the negative mode North Atlantic circulation during autumn and winter, which increases the frequency of major floods in both Atlantic and Mediterranean rivers of the Iberian Peninsula (Benito et al., 2008).

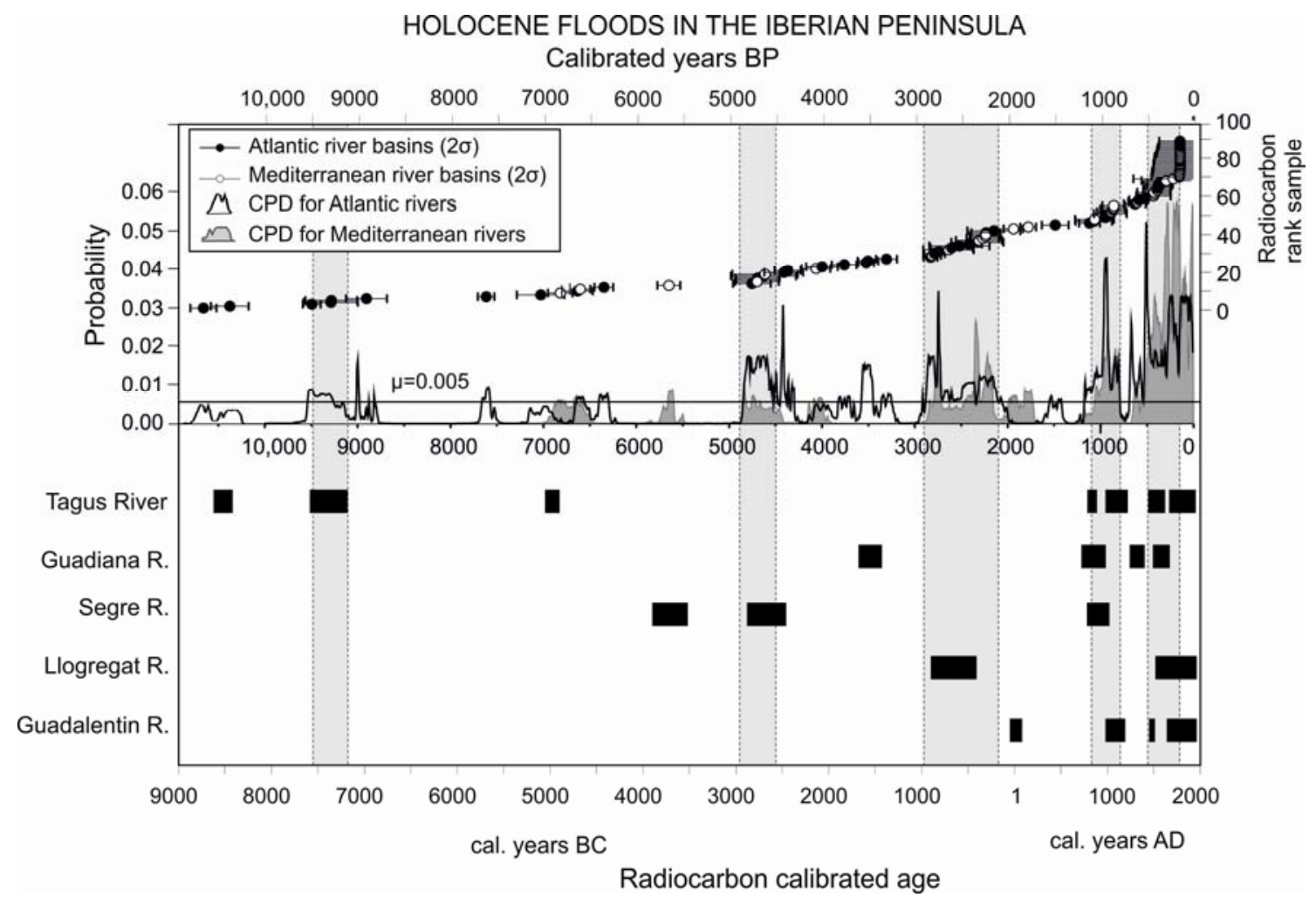

Figure 3. Upper: Cumulative probability density plots (CPD) of radiocarbon dates from floods and extreme fluvial event units of the Iberian Peninsula. Horizontal line indicates the mean probability above which a period of major flooding is inferred. Shaded vertical bars show periods of enhanced flood/fluvial activity above the mean and with at least three radiocarbon dates in 200 years. Black dots are radiocarbon age samples with 2-sigma geochronological age uncertainties indicated by the horizontal lines. Lower: Horizontal bars show periods of fluvial or flood activity inferred from stratigraphic evidence at individual sites. Tagus River (Benito et al., 2003a, b), Guadiana River (Ortega and Garzón, 2009), Huebra River (unpublished), Segre River (Rico, 2004), Llogregat River (Thorndycraft et al., 2004, 2005), and Guadalentín (Benito et al., 2010). 
Over the last millennium, episodes of high flood frequency and magnitude identified in the probability analysis can be compared with documentary flood data, except for the last 300 years because of poor chronological resolution of radiocarbon dating (Benito et al., 2008). A period of increased flooding in Iberian Atlantic rivers between 1100-800 cal. BP is also apparent in written documentary records (Benito et al., 2003b), and was associated with unusually wet winters. The largest historical flood peak discharges since AD 1500 occurred when the North Atlantic Oscillation during the winter months was in its negative phase (Benito et al., 2003b, 2008). In Iberian Mediterranean catchments, documentary sources indicate the greatest flood severity during AD 1580-1620 and AD 1840-1870 (Barriendos Vallve and Martín Vide, 1998; Llasat et al., 2005). The absence of slackwater deposits between 800-500 cal. BP highlights a period of particularly low frequency of large floods that is also evident in the documentary record (Benito et al., 2003b). However, this period (800-500 cal. BP) comprises an important phase of accelerated aggradation in Spanish alluvial valleys linked to land-use change (Butzer, 1980), that resulted in the burial of many irrigation structures (Vita-Finzi, 1969; Butzer et al., 1985).

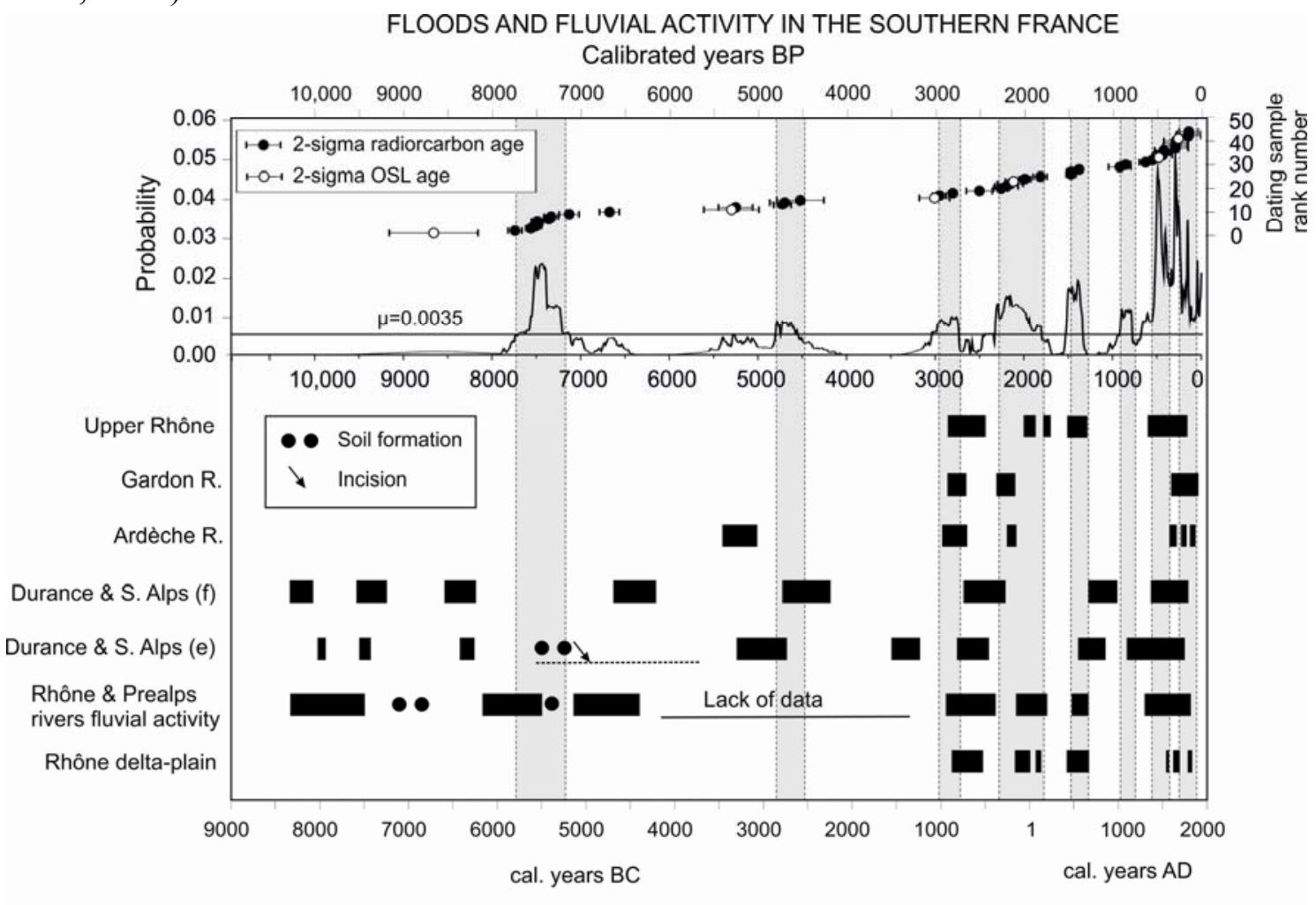

Radiocarbon calibrated age

Figure 4. Upper: Relative CPD plots of radiocarbon dates from floods and extreme fluvial events units of southern France. Horizontal line indicates the mean probability above which a period of major flooding is inferred. Shaded vertical bars show periods of enhanced flood/fluvial activity above the mean and with at least three dates in 200 years. Black dots are radiocarbon age samples and white dots OSL dates with 2sigma geochronological age uncertainties indicated by the horizontal lines. Lower: Horizontal bars show periods of fluvial or flood activity inferred from stratigraphic evidence at individual sites. Upper Rhône (Salvador et al., 2005), Gardon River (Sheffer et al., 2008), Ardèche River (Sheffer et al., 2003). Durance and southern-Alps rivers * (Jorda and Provansal, 1996; Jorda et al., 2002), Durance and southern-Alps rivers * (Miramont, 1998), Rhône and Prealps rivers fluvial activity* (Berger and Brochier, 2000; Berger, 2003) and Rhône deltaic plain* (Arnaud-Fassetta, 2007). * Periods of fluvial activity interpreted by 
Arnaud-Fassetta et al., 2010. The arrow indicates incision, and black dots show a period of soil development (after Arnaud-Fassetta et al., 2010).

Holocene alluvial records in France related to extreme hydrological events are frequent in floodplains of the Rhône River (Arnaud-Fassetta, 2004), southern-Alps rivers (Jorda et al., 2002) and pre-Alps streams (Berger and Brochier, 2000) (Fig. 2; Table 1). However, most of these alluvial records do not cover the entire Holocene, particularly before the Gallo-Roman period (50 BC to 500 AD; Arnaud-Fassetta et al., 2010). A number of studies have been conducted on archaeological sites where there were anthropogenic influences on alluvial deposition (e.g. region Lyonnaise, Salvador et al. 2002).

In the compiled database only those ages from sediments that have been described as being related to flood-related deposition have been used in the summed probability analysis. In southern France the sum probability plot is composed of 38 radiocarbon dates and 6 OSL ages, of which 22 are slackwater flood deposits and 22 floodplain units. Samples from the Rhône delta were not included in the analysis, nor were radiocarbon ages from archaeological sites, colluvial and alluvial fans. The probability sum shows eight major date clusters during the Holocene occurring at 7800-7150, 4800$4500,3000-2750,2300-1750,1500-1350,950-800,600-400$ and 250-100 cal. BP (Fig. 4; Table 2). Despite the paucity of radiocarbon data for this region, these flood episodes can be recognised in multiple descriptions from site-based chronologies.

Age clusters obtained from the probability plot show that the main periods of extreme hydrological events are regional in scale. The earliest cluster of hydrological extreme events is dated to 7800-7150 cal. BP (Fig. 4) that occurred under a drier and seasonally contrasted climate and heavy torrential rains (Berger et al., 2002; Berger and Guilaine, 2009). In the Citelle River, alluvial sediments show a succession of high flood frequency episodes (8100-8000, 7600-7500 7250-7050 cal. BP), lasting for one to two centuries, punctuated by hydrological stability and incipient soil formation (Berger et al., 2002). A regional river incision episode that affected most rivers in southern France occurred between 7200 and $6800 \mathrm{cal}$. BP that has been attributed to torrential discharges (Berger and Brochier, 2000). However, depositional evidence of this high fluvial activity is uncommon, with only one radiocarbon date during the period 7100-7000 cal. BP (Fig. 4). The entrenched valleys were partially infilled by fine sediments until 6500 $6300 \mathrm{cal}$. BP associated with an increase of humidity under a higher oceanic influence with low torrential activity (Berger and Brochier, 2000), which is supported by our CPDF analysis.

During the last 3000 years, the summed probability plot shows peaks at 3000-2750, 2300-1750, 1500-1350, 950-800, 600-400 and 250-100 cal. BP (Fig. 4). These periods were characterised by frequent channel avulsion in the lower Rhône river and delta area (Arnaud-Fassetta and Landuré, 2003; Arnaud-Fassetta et al., 2010). Periods of increased 
fluvial activity are also recorded at this time in the Durance River (Jorda and Provansal, 1996, Jorda et al., 2002), southern-Alps rivers (Miramont et al., 1999) and middle Rhône and pre-Alps rivers (Berger, 2003). The flood cluster at 3000-2750 cal. BP overlaps with a longer period (4200-2400 cal. BP) of substantial change in the hydrodynamics of the Rhône delta (Vella, 1999, Provansal et al., 2002). This period coincides with local torrential discharges in the southern-Alps and pre-Alps regions (Provansal et al., 2002). The 2300-1750 cal. BP flooding period (highest flood frequency from $100 \mathrm{BC}$ to $\mathrm{AD} 200$ ) was characterised by predominantly wet conditions (Provansal et al., 1999) leading to higher river channel and floodplain sedimentation rates (Arnaud-Fassetta, 2002, Arnaud-Fassetta and Landuré, 2003). This aggradation phase $\left(1^{\text {st }}-2^{\text {nd }}\right.$ century $\left.A D\right)$ in the Rhône catchment was probably enhanced by human activity and land-use change (Salvador et al., 2002; Berger, 2003). Later flood periods in French Mediterranean rivers at cal. AD 1025-1150 (only 3 dates), cal. AD 1350-1550 and cal. AD 1650-1850 partly coincide with those recorded in the Spanish rivers. In the River Durance increased flood frequency resulting from larger spring and winter rainfall was recorded at AD 1330-1410, AD 1550-1610 and AD 1750-1810, with 4-5 floods per decade being reported in each of these periods (Guilbert, 1994).

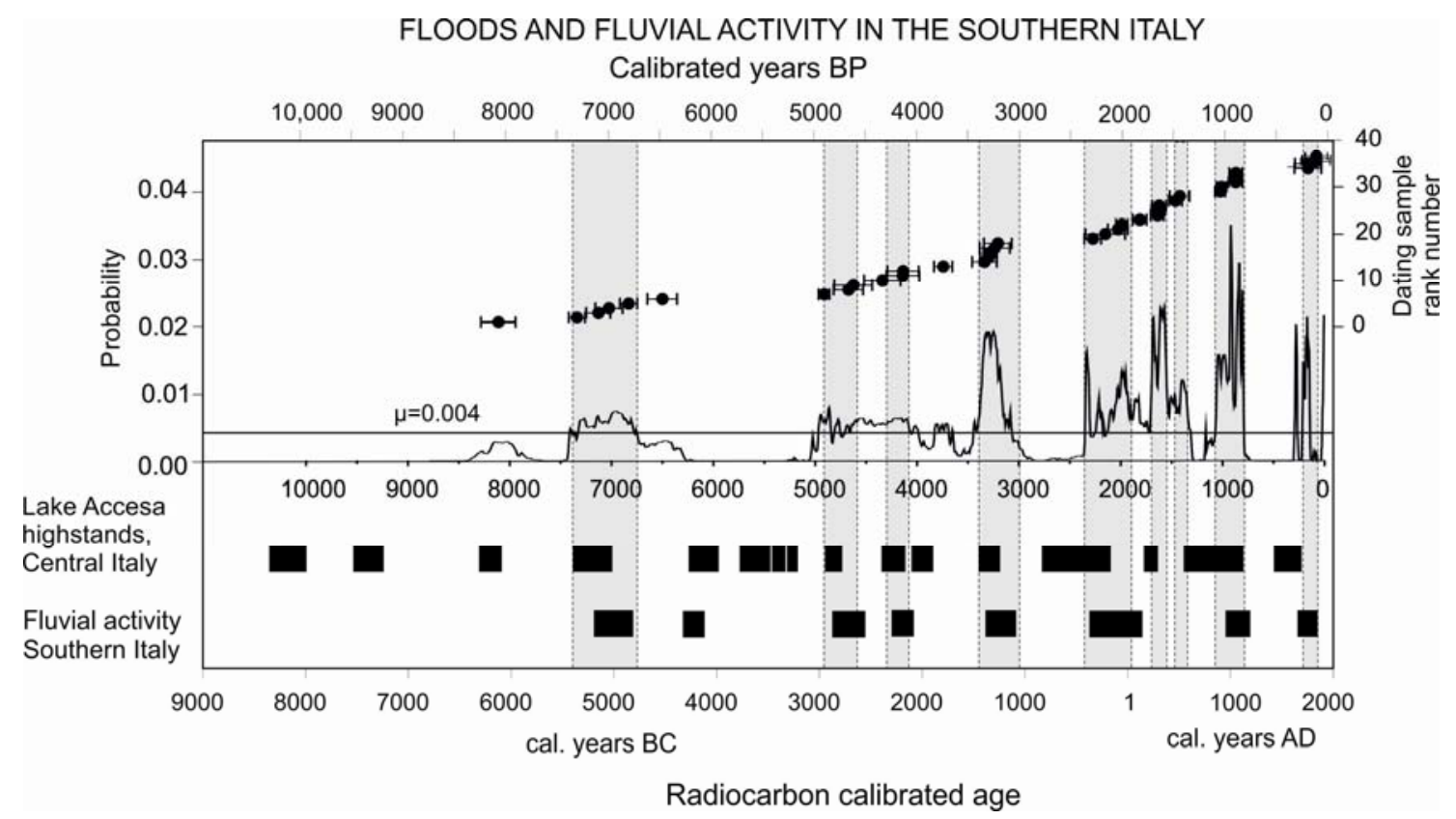

Figure 5. Upper: Relative CPD plots of radiocarbon dates from floods and extreme fluvial events units of southern Italy (modified from Piccarreta et al., 2011). Symbols as in Figure 3. Lower: Horizontal bars show: Lake Ledro-1, Flood deposit frequency recorded in detrital layers in Lake Ledro; Lake Accesa lake-level highstands related to wetter climatic conditions in central Italy (Magny et al., 2007),. Submillennial flood deposit frequency, i.e. above the millennial trend. Lake Ledro flood frequency after Vannière et al., (2013); Basilicata fluvial activity in the Bradano, Basento and Cavone rivers (Piccarreta et al., 2011).

In southern Italy, the analysis is mainly based on data from Piccarreta et al. (2011) with some minor additions. The data set is composed by 34 fluvial radiocarbon ages from the Bradano $\left(2765 \mathrm{~km}^{2}\right)$, Basento $\left(1537 \mathrm{~km}^{2}\right)$ and Cavone $\left(675 \mathrm{~km}^{2}\right)$ rivers. The probability 
plot shows nine Holocene flood clusters at 7400-6750, 4800-4600, 4200-4100, 34503000, 2350-1850, 1700-1600, 1500-1400, 1050-800 and 200-100 cal. BP (Piccarreta et al., 2011; Fig. 5, Table 2). Floods in southern Italy are currently related to autumn and winter rainfalls associated with Mediterranean depressions, northern troughs reaching the Mediterranean, or depressions coming from northern Africa (Piervitali and Colacino, 2003). The period 7400-6750 cal. BP coincides with a return to cool and wetter conditions that led to higher lake levels in central Italy between 9000 and 7000 cal. BP (Magny et al., 2007; Giraudi et al., 2011 Fig. 5). High resolution lake records from Lake Accesa (Magny et al., 2007; 2009) and Lake Fucino (Giraudi, 1998) show highstands at 4200-4000 and 3500-3200 cal. BP, overlapping with periods of high fluvial activity in southern Italy (Piccarreta et al., 2011, Fig. 5).

Several studies have reported increasing flood frequency overlapping our flood clusters at 2350-1850, 1700-1600 and 1500 and 1400 cal. BP. Between 2100-1900 cal. BP the frequency of large floods in the Tiber River at Rome increased (Camuffo and Enzi, 1995) and led to high sediment production and progradation of the delta and coastal areas (Bicket et al., 2009). An investigation of the alluvial stratigraphy of the Arno and Serchio rivers in western Tuscany reported the discovery of at least 16 well-preserved Roman ships, most probably destroyed by flows generated by levee crevassing of the Arno River (Benvenuti et al., 2006; Mariotti-Lippi et al., 2007). Radiocarbon dating of these shipwrecks and other archaeological wood remains supported with historical data demonstrated major flooding at 200 BC, 50 BC- AD 50, AD 150, 375, 500-700 and 900. Similar periods of flooding on the Tiber are also recorded in documentary sources with the exception of the episode around AD 375 (Camufo and Enzi 1995). Documented periods of high flood frequency in the Tiber River coincided with soil burial by alluvial sediments in the Apennines (Giraudi, 2005). In central and northern Italy, alluvial aggradation became evident immediately after the $3^{\text {rd }}$ century AD, which coincides with the economic and demographic crisis of the Roman Empire leading to the loss of the land preservation systems (Cremonini et al., 2013). However, the most active alluvial phase that buried the soils in the Apennines occurred during the sixth and seventh centuries AD (Veggiani, 1979, 1983; Cremaschi and Gasperi, 1989; Giraudi, 2005). A remarkable extreme event, the so-called 'Paul the Deacon Deluge' occurred in AD 589, resulting in catastrophic flooding producing channel avulsions and extensive sedimentation in central and northern Italy (Cremonini et al., 2013). Similar events probably occurred in the years AD 502, 580, 608-615, 676 and 716.

Over the last 1000 years the probability plot has relatively poor resolution, with two flood periods identified at 1050-800 and 200-100 cal BP. Higher resolution documentary data in the Tiber River indicate frequent flooding at AD 1400-1500 and 1600-1700, with the periods AD 1000-1400, 1500-1600 and 1700 onwards characterized by low flood frequencies (Camuffo and Enzi, 1995). 


\subsection{North-west Africa}

The meta-data analysis for Mediterranean north-west Africa comprises dated flood units from the lower Kert $\left(2710 \mathrm{~km}^{2}\right)$ and lower Moulouya $\left(53,500 \mathrm{~km}^{2}\right)$ rivers in north-east Morocco and from the Medjerda river $\left(23,500 \mathrm{~km}^{2}\right)$ in northern Tunisia (Zielhofer et al. 2008, 2010; Zielhofer and Faust 2008; Fig 2; Table 1). Holocene fluvial deposits in the region are characterized by fine-grained clastic overbank units, which are well-stratified and because of their cohesive nature are resistant to erosion. These floodplain sequences contain exceptionally well-preserved Holocene flood records.

The semi-arid Kert catchment (Morocco) has an average annual precipitation ranging from $200 \mathrm{~mm}$ in the lowlands up to $700 \mathrm{~mm}$ in the Rif Mountains with two mean monthly maxima in October and April. Barathon et al. (2000) and El Amrani et al. (2008) have identified at least three Holocene terrace levels in the lower Kert River and ${ }^{14} \mathrm{C}$ dating indicates major flooding between 4500-1400 cal. BP (El Amrani et al. 2008). This flooding episode is also recorded in the Lower Moulouya River (Fig. 6; Table 2).

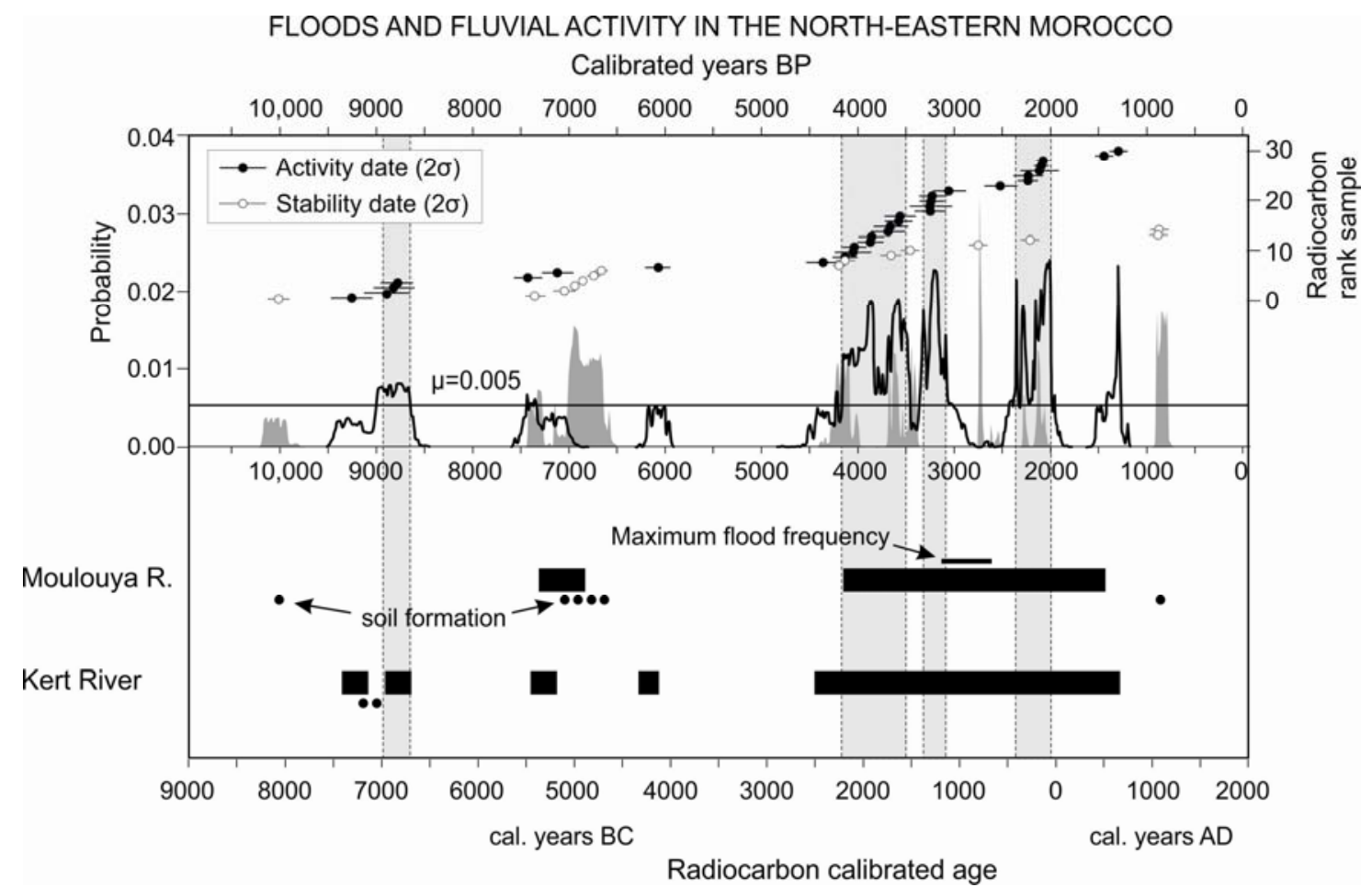

Figure 6. Moroccan Holocene flood activity. The figure shows Holocene relative frequency plots of ${ }^{14} \mathrm{C}$ data. The solid black line represents the alluvial activity plot, the greyish shading documents the alluvial stability plot. The basal part of the figure shows periods of major flooding from detailed Moroccan alluvial records: Kert River (El Amrani et al. 2008 and Zielhofer et al. 2008) and Moulouya River (Ibouhouten et al. 2010 and Zielhofer et al. 2010).

In the Moulouya catchment high rainfall intensity and strong monthly variability lead to high fluctuations in water discharge (Snoussi et al., 2002) with autumn (October) and spring (April) mean monthly precipitation maxima. Although early and mid-Holocene flood units are preserved, the Moulouya cohesive overbank deposits contain mostly palaeoflood records of consistent centennial-scale resolution between 4000 and 1400 
cal. BP, and a maximum in flood frequency between 3200 and 2700 cal. BP (Zielhofer et al., 2010). At that time the arid to semi-arid river system shows increased flooding during a period of a generally more arid climate indicated by the charcoal record of the Lower Moulouya (Linstädter and Zielhofer 2010). Higher flood frequencies between 3200 and $2700 \mathrm{cal}$. BP in the lower Moulouya are associated with increased floodplain aggradation in the middle reaches of the Medjerda valley in northern Tunisia (Faust et al., 2004).

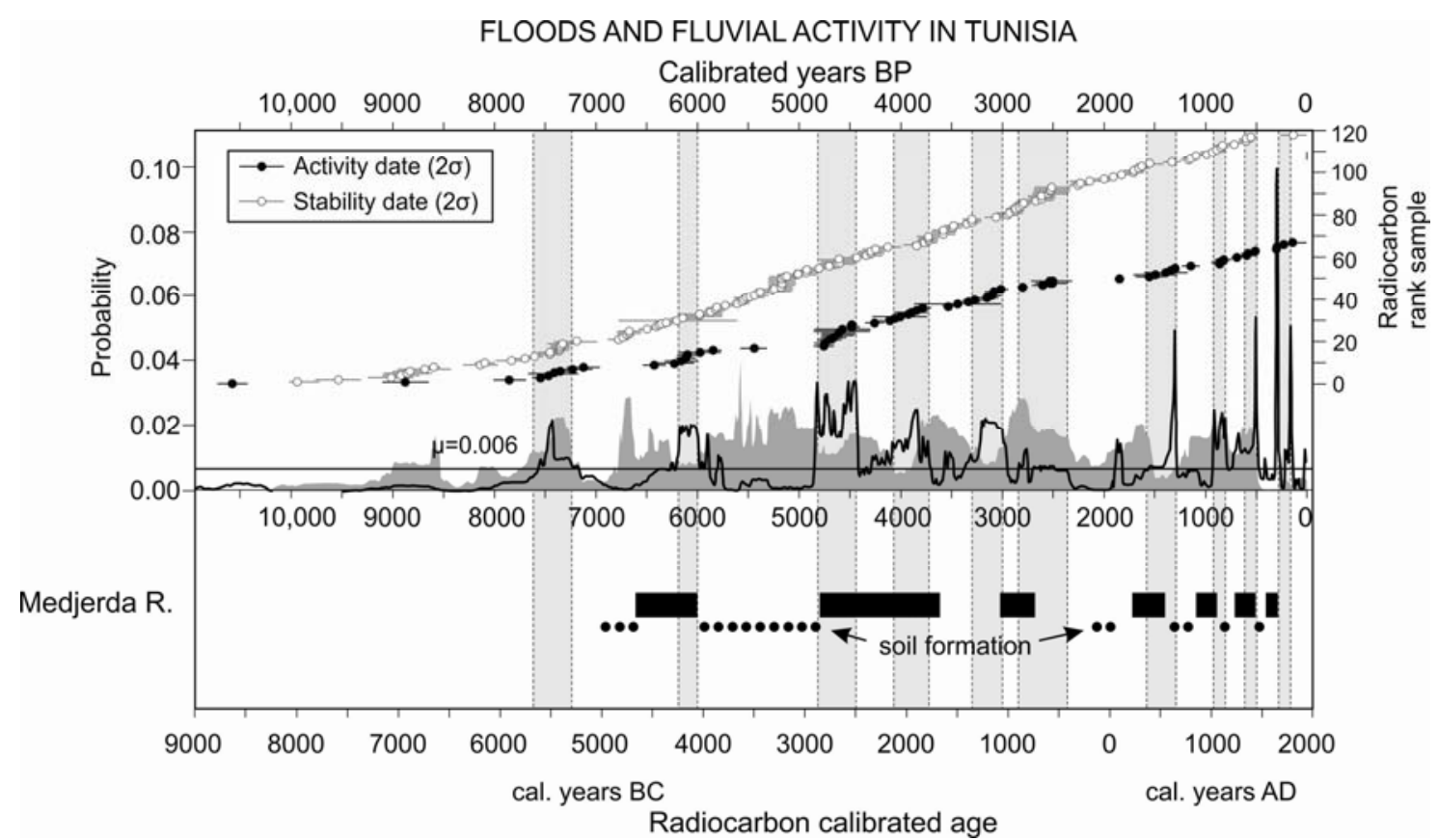

Figure 7. Tunisian Holocene flood activity. The figure shows Holocene relative frequency plots of ${ }^{14} \mathrm{C}$ data. The solid black line represents the alluvial activity plot, the greyish shading documents the alluvial stability plot. The basal part of the figure shows periods of major flooding from the detailed Medjerda alluvial record following Faust et al. (2004) and Zielhofer et al. (2004).

The Oued Medjerda (Fig. 2; Table 1) is the main perennial river system in Tunisia and eastern Algeria. The stratigraphic and palaeopedological investigation of the middle parts of the Medjerda valley has identified seven floodplain aggradation phases over the last 12,000 years separated by stable soil formation phases (Faust et al. 2004, Zielhofer et al., 2004). The onset of the Holocene (11,800 cal. BP) is marked by fine sedimentation lasting until 6600 cal. BP, reflecting decreased flooding and geomorphological stability in the catchment. At 6600 cal. BP, the stable period is interrupted by sedimentation of sandy material (Zielhofer et al. 2004). After 6600 cal. BP overbank sedimentation of clays and silts occurred in most parts of the floodplain on which a distinct soil was formed (Fig. 7). This period of mid-Holocene geomorphological stability and pedogenesis is characterised by a ubiquitous welldeveloped alluvial soil dated to 5600-4800 cal. BP within the middle Medjerda valley (Zielhofer et al. 2004, 2009), which is also documented in adjacent catchments in central Tunisia (Molle, 1979). This alluvial soil formed in response to a fall in groundwater level and represents relatively arid conditions in a phase of major mid- 
Holocene climatic change (Fletcher and Zielhofer 2013). After 4700 cal. BP extensive fluvial deposits covered the mid-Holocene soil with maximum sedimentation rates around 3000 cal. BP. During the Roman period a phase of decreased flooding and alluvial soil formation took place between 2200 and 1700 cal. BP (Faust et al., 2004). At 1600 cal. BP renewed fluvial sedimentation occurred that was interrupted by several phases of soil formation between 1400 and 1200, 900 and 700 and around 500 cal. BP. At ca. 400 cal. BP devastating floods occurred in the entire Mid-Medjerda floodplain (Faust et al. 2004).

Changes in Holocene flood dynamics are reconstructed using a meta-analysis of 242 radiocarbon dates (Table 1) from overbank sediments in north-east Morocco and central Tunisia (Figs. 6 and 7). The meta-data comprise two data sets: (1) ${ }^{14} \mathrm{C}$ dates of redeposited bone and charcoal from overbank deposits within facies indicative of active fluvial dynamics or 'activity dates' (Figs. 6, 7); (2) ${ }^{14} \mathrm{C}$ dates from bulk samples of alluvial soils and/or dating in situ evidence for human occupation (e.g. buried hearths) in the floodplain representing short- or long-term floodplain stability ('stability dates'), or periods of minor floods (Zielhofer and Faust 2008; Ibouhouten et al., 2010; and Zielhofer et al., 2010). Fluvial 'activity dates' and 'stability dates' should be mutually exclusive and for the north-east Moroccan data this is generally the case for the early and mid-Holocene (Fig. 6). However, between 4500 and 2000 cal. BP there is overlap of floodplain stability and aggradation chronologies in the Kert and Moulouya rivers. During this period short-term flood events are separated by numerous short-term 'stable' walking horizons in the floodplain (Zielhofer et al. 2010).

In the North-eastern Moroccan basins, the probability plots show at least four Holocene fluvial activity clusters at 8900-8700, 4200-3500, 3300-3100, and 2500-2100 cal. BP (Fig. 6). As the database is only based on two fluvial systems the lack of fluvial activity particularly over the last millennium may reflect the paucity of chronological data for this period. Regarding the central Tunisian cumulative probability plots (Fig. 7), the analysis shows a higher number of periods with enhanced fluvial activity and floods at 7600-7150, 6200-6000, 4800-4500, 4100-3700, 3300-3000, 2850-2350, 1600-1300, 900-800, 700-500 and 300-200 cal. BP. These flood periods coincide with low rates of pedogenesis. Here, periods of soil formation from 6800-6600, 5900-4800, 4500-4100, 3700-3300, 3000-2800, and 1800-1600 cal. BP coincide with periods of low floodplain aggradation. At least three out of four Moroccan flood episodes overlap those recorded in Tunisian rivers during the mid-Holocene.

\subsection{Eastern Mediterranean region}

The eastern Mediterranean (Fig. 2; Table 1), which for the purposes of this review includes mainland Greece (Fuchs and Lang, 2001; Fuchs and Wagner, 2003, 2005; Jing and Rapp, 2003; Koukouvelas et al., 2001; Lespez, 2003; Pavlides et al., 2004; Pope and Wilkinson, 2006) and islands (Booth, 2010; Deckers, 2005; Maas, 1998; Maas et 
al., 1998; Macklin et al., 2010; Zacharias et al., 2009), Albania (Carcaillet et al., 2009), Turkey (Beach and Luzzadder-Beach, 2008; Casana, 2008) and Israel (Goldberg, 1984; Greenbaum et al., 2000). It is the most seismically active region of the Mediterranean (Stiros, 2009) and has significant hydrological variability with average annual rainfall ranging from more than $1500 \mathrm{~mm}$ in the Pindus Moutains of north-west Greece to less than $200 \mathrm{~mm}$ in the hyper-arid catchments of southern Israel. Most studies of Holocene flooding in this region have been carried out in relatively small steepland (cf. Macklin et al., 1995) and mountain catchments primarily in Greece on the island of Crete (Maas et al., 1998; Macklin et al., 2010; Fig. 8). Nearly 75\% of the dated units (78 in total, 47 OSL and $31{ }^{14} \mathrm{C}$ ) come from Greece, including 45 out of the 47 OSL ages, with Crete contributing $58 \%$ of all assays. The number of dates from Turkey and Israel is limited. Holocene flooding periods are evident at 7800-7150, 4100-3700, 3400-3200, 19001600, 1200-1100, 900-600 and 250-85 cal. BP (Fig. 8). There are, however, very few or no recorded events found between 5900-5300 and 3000-2500 cal. BP or at c. 1250, 1000,600 and $300 \mathrm{cal}$. BP, which indicate a reduced frequency of floods at these times.

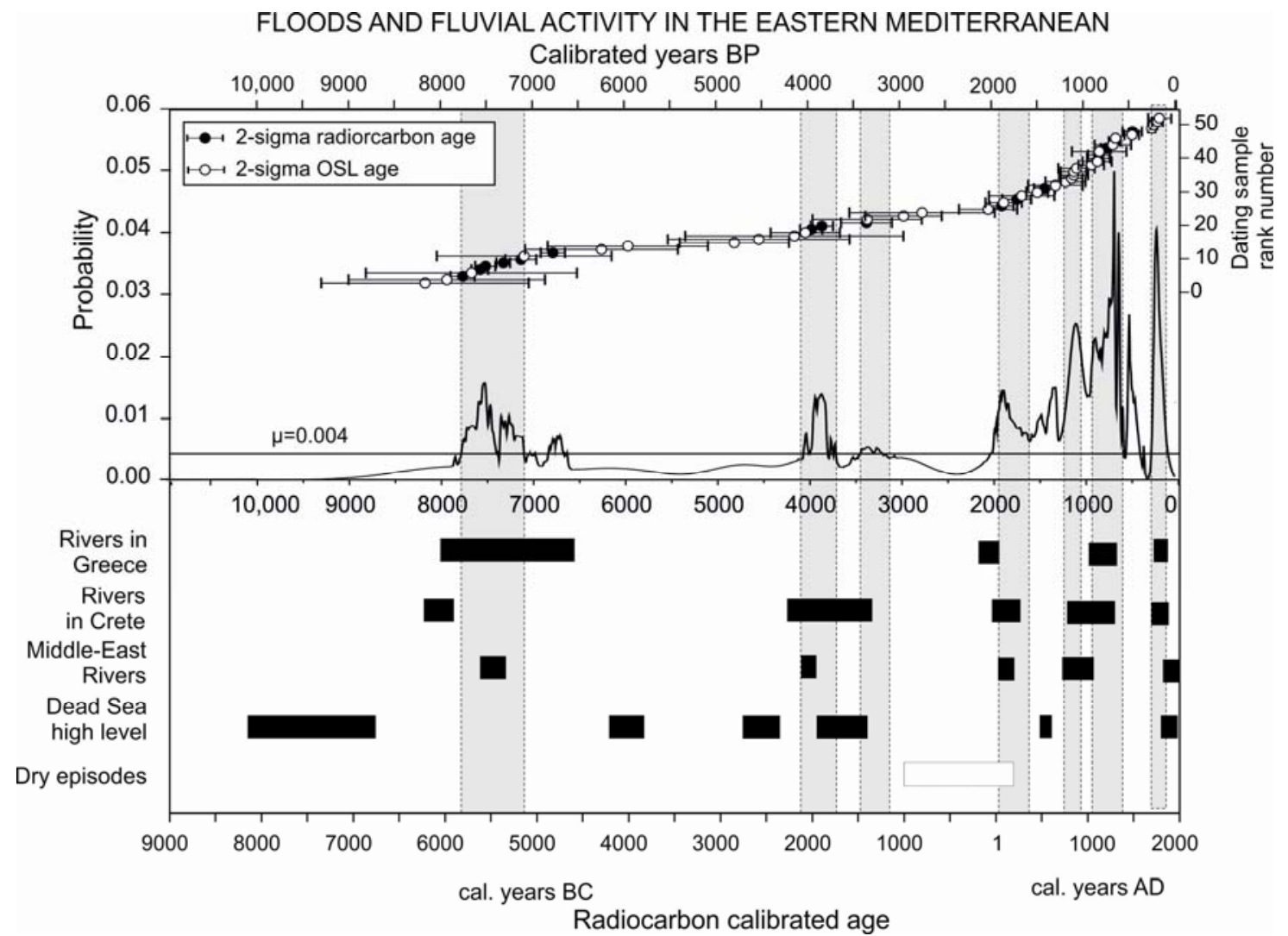

Figure 8. Upper: Relative CDP plots of geochronological dates from floods and extreme fluvial event units of eastern Mediterranean rivers. Symbols as in Figure 3. Lower: Horizontal bars show periods of fluvial activity or high lake levels at different sites and subregions. Greece rivers (this study), Crete rivers (this study), Middle-East rivers (Greenbaum et al., 2006), Dead Sea high level stand (Bookman et al., 2006), and dry episodes (Bookman et al., 2006). 


\subsection{Spatial and temporal correlation of flood episodes among regions}

In Table 2 major flooding periods in the Mediterranean over the last 10,000 years are listed. The number of flood episodes varies between ten recorded in Tunisia and four in Morocco. Taking the Mediterranean as a whole, we can identify several flood periods that are synchronous in multiple regions (Table 2) at 7400-7150, 4800-4600, 41003700 , 3300-3200, 2850-2750, 2300-2100, 1700-1600, 1500-1400, 950-800, ca. 300, 200-100 cal. BP. The temporal and spatial variability of flood clusters in the Mediterranean can provide a characterisation and classification of regional datasets reflecting hydroclimatic and atmospheric circulation connections. Direct comparison of flood episodes among regions is difficult due to different duration of the flooding periods; however this problem can be resolved by dividing flood periods in $100-\mathrm{yr}$ bins. A data matrix was constructed from the eight regional data sets with $n 100$-yr rows, where each row $i$ of the matrix contains binary data of either presence of flood activity $(k=1)$ or absence of flood activity $(k=0)$. The subsequent statistical analysis included only the last 5000 years, which contains the most complete fluvial chronology. A hierarchical agglomerative cluster analysis was applied using Jaccard's index (Jaccard, 1908) of similarity across all regions on a pairwise basis, accounting for shared presences of flood activity (Table 3). The highest similarities are found between the west and east Iberian Peninsula and these regions with southern France and Tunisia. A high dissimilarity was found between the Iberian Peninsula regions and the eastern Mediterranean whereas the latter showed similarities with Tunisia. Other significant relationships were found for southern France with southern Italy, and Morocco with Tunisia. In fact, Tunisia shows similar distance values in the proximity matrix for all regional records. A factor analysis was ran showing that $30 \%$ of the variance is explained by the first factor mostly defined by the Iberian regions and southern France (positive) and in a lesser extent by eastern Mediterranean and Morocco (inverse impact on the factor) (Table 4). The second component that explains an additional $20 \%$ of the variance is defined by positive values for Tunisia, Morocco and the eastern Mediterranean. A third and last factor was extracted, explained by positive impact of southern Italy and France and inverse impact of the eastern Mediterranean on the factor.

\section{Comparing flood episodes and proxy data}

The statistical analysis described above provides a classification of regional datasets based on temporal similarity, which suggests a dominant climatic control on the temporal distribution of flood episodes. In the following sections the regional patterns of flood periods are described in the context of climate and environmental changes.

\subsection{Early Holocene}

There are relatively few clusters of extreme hydrological events during the early and mid-Holocene and their extended duration (500-650 years) may reflect the limited number of dated units as a consequence of poor preservation of old deposits, particularly in steepland river systems with small catchments (Fig. 9; Table 2). Flood 
clusters are more frequent over the last 4000 years with a shorter duration (80-400 years), in part due to the greater number of dated units that increases the temporal resolution of the flood activity phases.

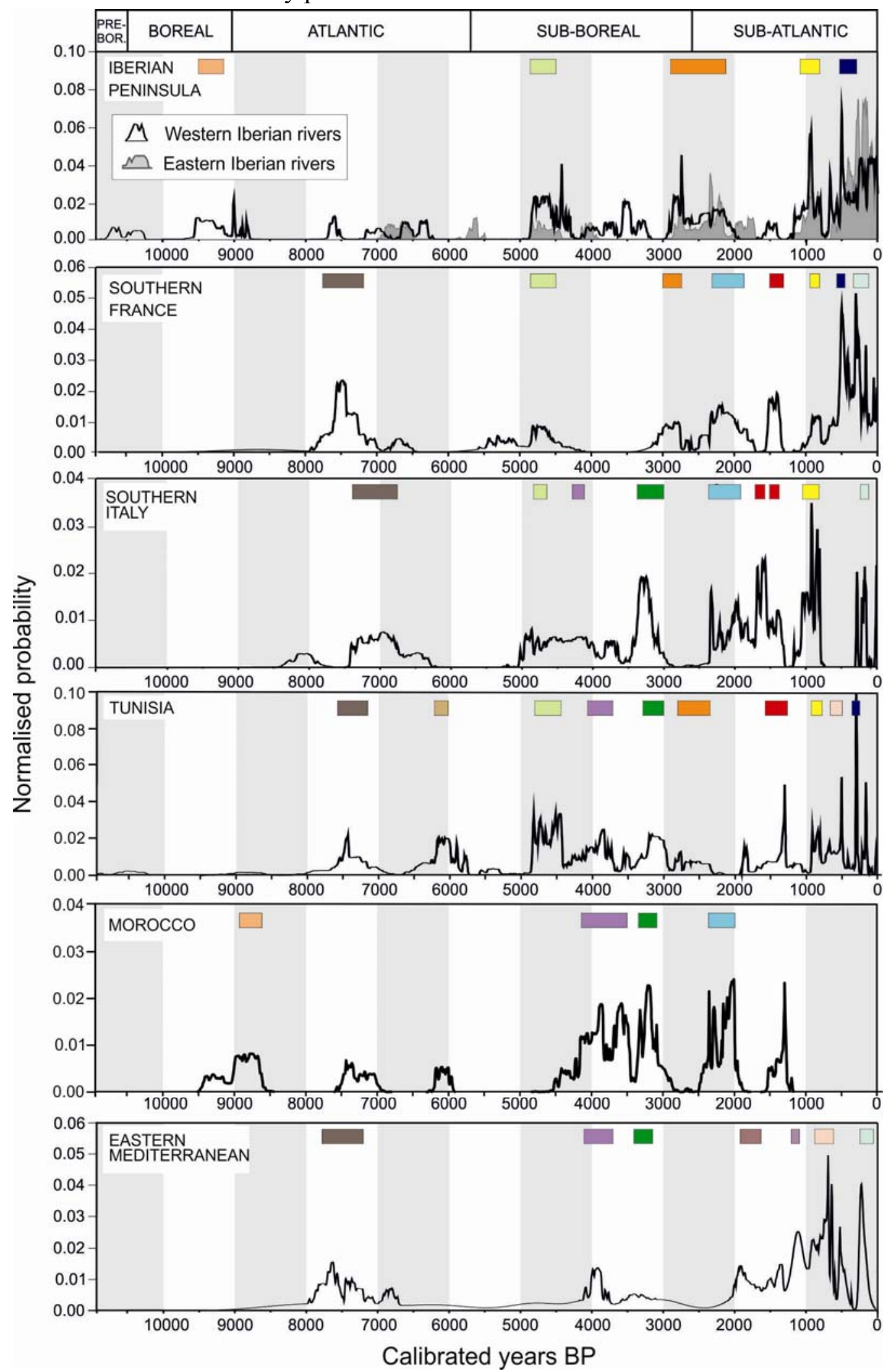

Figure 9. Upper: Relative CPD plots of radiocarbon dates from floods and extreme fluvial event units in different Mediterranean regions. Horizontal bars with colours indicate periods of major flooding referred to in Table 2. Shaded vertical lines are placed at intervals of one thousand years. 
The Iberian flood cluster (9500-9200 cal. BP) is in-phase with high lake levels in the Jura Mountains and the northern French Pre-Alps (9550-9150 cal. BP; Magny, 2004) likely reflecting their high sensitivity to North Atlantic circulation. There is no sedimentary evidence of frequent flooding between 8600-7800 cal. BP in the northwestern Mediterranean rivers, although this long period was punctuated by short pulses of fluvial activity reported in the Durance and southern-Alps rivers (Arnaud-Fassetta et al., 2010). Several proxy records indicate dry climatic conditions between 8500-8100 cal. BP reported from pollen record and lake-level studies in the Iberian Peninsula (Jalut et al., 2000; Carrión, 2002; González-Sampériz et al., 2006; Morellón et al., 2008), and in central Italy (Lago di Vico, Magri and Parra, 2002; Lago di Mezzano, Ramrath et al. 2000). The driest phase of this arid period occurred during the $8.2 \mathrm{ka}$ cold event (Alley and Agustsdottir, 2005) that caused an ecological crisis and enormous impact on the Mediterranean Mesolithic civilisation (Berger et al., 2002) that, for instance, in Iberia forced human migrations to more humid mountain areas (González-Sampériz et al., 2009). While Iberia showed a long period of aridity between 8600-7000 cal. BP, the eastern Mediterranean showed an increased flood activity at 7800-7150 cal. BP (Fig. 9) taking place in a context of more humid conditions between 7000 and $8000 \mathrm{cal}$. BP as documented in the speleothem record at the Soreq Cave (Bar-Matthews et al. 2003). This out-of-phase flood activity between the western and eastern Mediterranean regions reflects a bipolar climate see-saw in the Mediterranean at a centennial timescale also recognised at decadal time intervals since AD 900 in lake records of Spain and Turkey (Roberts et al., 2012).

This eastern Mediterranean episode of flood activity overlapped at 7600-7150 cal. BP with a period of high flood activity in southern France, Italy, and Tunisia (Fig. 9; Table 2). This period is characterised by a trend towards cooling conditions that peak at 7300 cal. BP, recorded in the isotopic signals of the GISP2 ice core (Alley et al., 1997) and in the ice rafting detrital content in the North Atlantic (Bond et al., 2001). Western Mediterranean pollen records (Alboran deep sea core MD95-2043) also show evidence for a major change towards cooler conditions around 7500 cal. BP (Fletcher and Sánchez Goñi, 2008; Fletcher and Zielhofer, 2013). Additionally, there is evidence for more humid conditions from the mountainous pollen record in Siles, SE Spain (Carrión 2002). However, unlike the earlier $8.2 \mathrm{ka}$ cold event, this episode produced a high north-south contrast in temperature and precipitation with increased lake levels in the Jura and North Alp regions (e.g. Lake Cerin; Magny, 2004) and dry conditions in North Africa (Magny et al., 2011). The aridification of the Mahgreb region between 8200 and 7300 cal. BP is believed to have been a major factor in the migration and rapid expansion of the Neolithic culture northwards to the western Mediterranean (CortésSánchez et al., 2012). This human crisis fits with a picture of hydrological change in North Africa and the central Mediterranean at 7600-7200 cal. BP as indicated in our fluvial records, with a pronounced seasonal and inter-annual variability of rainfall which 
would lead to frequent storms and flooding, in some cases favoured by an increase in fire activity (Tinner et al., 2009).

\subsection{Middle Holocene}

Relatively few flood units are recorded in the Mediterranean over the period 7000-5000 cal. BP, with the exception of Tunisian rivers that experienced floodplain aggradation at 6200-6000 cal. BP. The Holocene thermal maximum (c. 9,000 to 5,000 cal. BP) was characterized by warming over Northwest Europe that was balanced by cooling over southern Europe (Davis et al., 2003). This lower temperature resulted in a moisture balance of 50 to $200 \mathrm{~mm}$ greater than the present (Cheddadi et al., 1997; Davis et al., 2003). In the Spanish Mediterranean sector, the period from ca. 7500 to $5200 \mathrm{cal}$. BP represents the mesophytic optimum with forest development, low fire activity and relatively high lake levels (Carrión, 2002). In the Jarama River, a tributary of the Tagus River (central Spain), a period of floodplain stability was reported between 7000 and 5000 cal. BP (Wolf et al., 2013a). However, other downstream sedimentary records of the Tagus River indicate some mid-Holocene flood activity in the north-western Mediterranean region (two flood dates 6800-6700 cal. BP, Benito et al., 2003a). In particular, the Lower Tagus Valley recorded a high rate of flood-supplied suspended sediment at 6500-5500 cal. BP (Vis et al., 2010). The major phase of mid-Holocene soil formation in Northern and central Tunisia between 5500 and 4800 cal. BP (Faust et al. 2004, Zielhofer and Faust 2008) coincides with a major cooling phase in the northern hemisphere (Bond et al. 2001) and enhanced aridity in the central (Genty et al. 2006) and western Mediterranean (Yll et al. 1997, Carrión et al. 2010). The lack of fluvial activity reflects both a decrease in extreme hydrological events and improvement of land-cover conditions in the Mediterranean regions.

A major change occurred at c. $5000 \mathrm{cal}$. BP across the Mediterranean with an increase in the frequency of flood clusters suggesting a greater sensitivity to climatic and environmental changes. There may be three reasons for this: (1) later Holocene fluvial records are better preserved and, therefore, there is a larger number of dates from this period; (2) since the Bronze Age there has been a growing impact of land-use change on Mediterranean catchments that enhanced runoff and sediment production in river valleys; and (3) a transition to drier conditions after 5000 years ago increased hydrological variability with multi-decadal to multi-centennial episodes of flood-poor and flood-rich periods in response to changing atmospheric circulation patterns. The increased hydrological variance after 5000 cal. BP, related to a trend towards aridification, is in agreement with vegetation changes with a decline in deciduous broad-leaf trees and a spread of evergreen sclerophyllous taxa in the Mediterranean (Jalut et al., 2009).

A period of increased fluvial activity and flooding in the western-central Mediterranean occurred at 4800-4500 cal. BP recorded in the winter rainfall zone of Iberia (Duero and 
Tagus rivers; e.g. Benito et al., 2008; Vis et al., 2010; in the Guadalete at 4600-4300, Wolf et al., 2013b) and in the autumn-winter rainfall regions of Tunisia (Faust et al. 2004), eastern Spain, southern France (Vella, 1999; Arnaud-Fasseta, 2004) and southern Italy (Piccarreta et al., 2011). This period of major floods would indicate a negative NAO-type circulation in winter and autumn, and a high land-sea temperature contrast favouring cyclogenesis in the Mediterranean coastal regions (Benito et al., 2008). In the northern Mediterranean and northern French Pre-Alps lake records indicate high-water levels (e.g. Lake Preola, Sicily, Magny et al., 2011; and Lake Accesa, Central Italy, Toscana, Magny et al., 2007). In contrast, within south-east Spain this correlates with a long phase of aridification (Carrión, 2002; Jalut et al., 2000). In the eastern Mediterranean there is no evidence of fluvial activity at this time.

In the eastern Mediterranean there was renewed flooding at 4100-3700 cal. BP, particularly evident in fluvial systems of Crete (Macklin et al., 2010) and southern Israel (Greenbaum et al., 2006). A synchronous episode of flooding is also recorded in Tunisia, southern Italy and Morocco (Fig. 9; Table 2). This period is associated with a major increase in lake levels in the Dead Sea (Migowski et al. 2006) and low water levels in Lake Siles, south-east Spain (Carrión, 2002). A detailed study documenting lake-level changes in Lake Accesa, north-central Italy, and Maliq, Albania, recognized a phase of drier conditions at ca. 4100-3950 cal. BP bracketed by two periods of marked wetter conditions at 4300-4100 and 3950-3850 cal. BP (Magny et al., 2009). Short-term periods of increased flooding in central Tunisia match well with North Atlantic cooling, indicating a strong climatic link from 4700 cal. BP until today (Zielhofer and Faust, 2008).

\subsection{Late Holocene}

Human activities (e.g. deforestation, agriculture and grazing) over the last 5000 years have varied significantly across the Mediterranean both in time and space, providing heterogeneity in the hydrological response. For instance, agricultural practices in southern France at ca. 5000 cal. BP resulted in increasing sediment yield, although the highest erosion rates occurred during cold/wet periods such as the Late Bronze Age (1200-700 BC), or the Late Medieval period (Jorda et al., 1991; Jorda and Provansal, 1996). In Spain, widespread changes in vegetation cover due to human activities did not occur until c. 2000 cal. BP, and in mountain communities demographic pressure and expansion of agriculture occurred only in the last two centuries (Burjachs et al., 1997; Santos et al., 2000; Carrión, 2002). The results based on CDPF meta-analysis do not show apparently a direct link to human disturbance at regional scales. However, human impacts on runoff and sediment production at a catchment scale cannot be neglected at least over the last millennium, particularly in small basins. There is well-documented Late Holocene evidence for a strong increase in sediment production due to human impact from the Medjerda basin in northern Tunisia. Here, the climatic impact on 
overbank deposition is intensified by human land-use practices (Faust et al. 2004, Zielhofer 2006).

In the north-western and central Mediterranean major flooding periods in the last 3000 years can be identified at 2850-2700, 2300-1850, 1500-1350, 1050-800 and ca. 300 cal. BP, whereas in the eastern Mediterranean flooding occurred at 1900-1600, 1200-1100, 900-600 and 250-85 cal. BP. This opposing flood pattern shows, as in the earlier Holocene, a rhythmically asynchronous timing of major flood episodes between the western and the eastern Mediterranean regions.

A flood cluster at 2850-2250 cal. BP is recorded in slackwater flood deposits and floodplain environments in the north-western and central Mediterranean regions, while no data are available for southern Italy. In the Jarama River, a period of accelerated sedimentation is reported at about 2800 cal. BP (Wolf et al., 2013a) while other archives revealed a transition from arid to humid conditions around 2900 cal. BP in east Spain (Roca and Juliá, 1997). This flooding episode is coincident with a decline in solar activity around 2800 cal. BP (van Geel et al., 1998), characterized by a widespread cooling in the North Atlantic region (Risebrobakken et al., 2003), relatively wet conditions in western Europe (Martín-Puertas et al., 2009) and flooding in different regions of western and central Europe (Macklin et al., 2006). In the Llobregat River (northeast Spain) the magnitude of floods produced during this period was double that of the floods recorded during the $20^{\text {th }}$ Century (Thorndycraft et al., 2005).

Flooding in western Iberia decreased during the Roman period (100 cal. BC), while in the eastern Mediterranean flooding increased between 1900-1600 cal. BP after two millennia of very low fluvial activity. Dead Sea levels reached a high stand of $395 \mathrm{~m}$ b.s.l. during the Roman period (ca. 1st century BC; Enzel et al., 2003; Bookman et al., 2004). This opposite pattern of fluvial activity reflects a temperature increase from the 2650 cal. BP cold event until the $1^{\text {st }}$ century AD (Davis et al., 2003). Flood-dominated regimes, recorded by channel avulsion and fluvial metamorphosis, were evident between 100 cal. BC to cal. AD 200 in the lower Rhône and Pre-Alps rivers (southern France; Arnaud-Fassetta et al., 2010), and the Arno and Serchio rivers in western Tuscany (Italy, Benvenuti et al. 2006; Mariotti-Lippi et al. 2007).

The first millennium is characterised by low fluvial and flood activity in the western and central Mediterranean with the exception of a peak at ca $1400 \mathrm{cal}$. BP. This period of high flood activity during the $6^{\text {th }}-7^{\text {th }}$ centuries $\mathrm{AD}$ was prominent in Tunisia, southern Italy and southern France (Fig. 9). In the eastern Mediterranean significant floods occurred later at 1200-1100 cal. BP at the onset of the Medieval Climatic Anomaly (MCA, AD 950-1250). Moreover, we have evidence for high sediment production during the Medieval Climatic Anomaly in Tunisia (Faust et al. 2004). 
During the last 1000 years fluvial activity increased in the north-western Mediterranean at the end of the MCA and during the LIA, notably in the $10^{\text {th }}$, late $15^{\text {th }}$ and late $18^{\text {th }}$ centuries AD (Benito et al., 2008; Wolf et al., 2013a,b), which all coincided with relatively wet and cold climatic conditions (Luterbacher et al., 2012). Conversely, periods of low flood frequency in the eastern Mediterranean are evident at AD 1225, 1600 and 1825 . The radiocarbon age uncertainty particularly over the last 300 years makes it difficult to establish precise periods of overlapping flood activity across the Mediterranean during more recent historical times. The relationship between recent climate change and flooding in the Mediterranean is difficult to evaluate because of extensive human modification of floodplains and river regulation (e.g. dams). Nevertheless, it does appear that more frequent and severe floods were recorded in the late $15^{\text {th }}$ and late $18^{\text {th }}$ century than in the 20th century (Sheffer et al., 2008). Indeed, in Mediterranean steepland catchments, less affected by human activity, a significant reduction in both the frequency and magnitude of major floods is evident in the second half of the $20^{\text {th }}$ century (Macklin et al., 2010; Machado et al., 2011).

\section{Atmospheric circulation, climate drivers and flooding}

In the western Mediterranean large inter-annual variability of river flow is related to the North Atlantic Oscillation (NAO; Trigo et al., 2004). In the Iberian Peninsula, the negative mode of the NAO index during the autumn and winter months has a strong impact on flooding at seasonal, monthly and even weekly scales (Salgueiro et al., 2013). The link between the NAO index and the frequency of extreme events in Iberia can also be detected through historical documents (Benito et al., 2003b, Ortega and Garzón, 2004; Benito et al., 2008) as well as in annually resolved paleoflood records from lakes (Corella et al., 2014). Some periods with high flood frequency show a correlation with phases of maximum solar activity (Vaquero, 2004), although this relationship is not always consistent (Benito et al., 2004).

For the Mediterranean rivers of eastern Spain, southern France and southern Italy, with a flood regime driven by precipitation in the autumn and early winter months, the relationship between climatic fluctuations and floods is more complex but southward migration of westerlies increases instability and development of mesoscale convective systems leading to intense rainfall and flooding (Llasat, and Puigcerver, 1990). Annual palaeoflood records from Lake Montcortés (north-east Spain, Corella et al., 2014) show that floods are related to the negative NAO mode during the autumn months, with a higher flood frequency at transitional climatic periods, such as the onset and end of the LIA. 


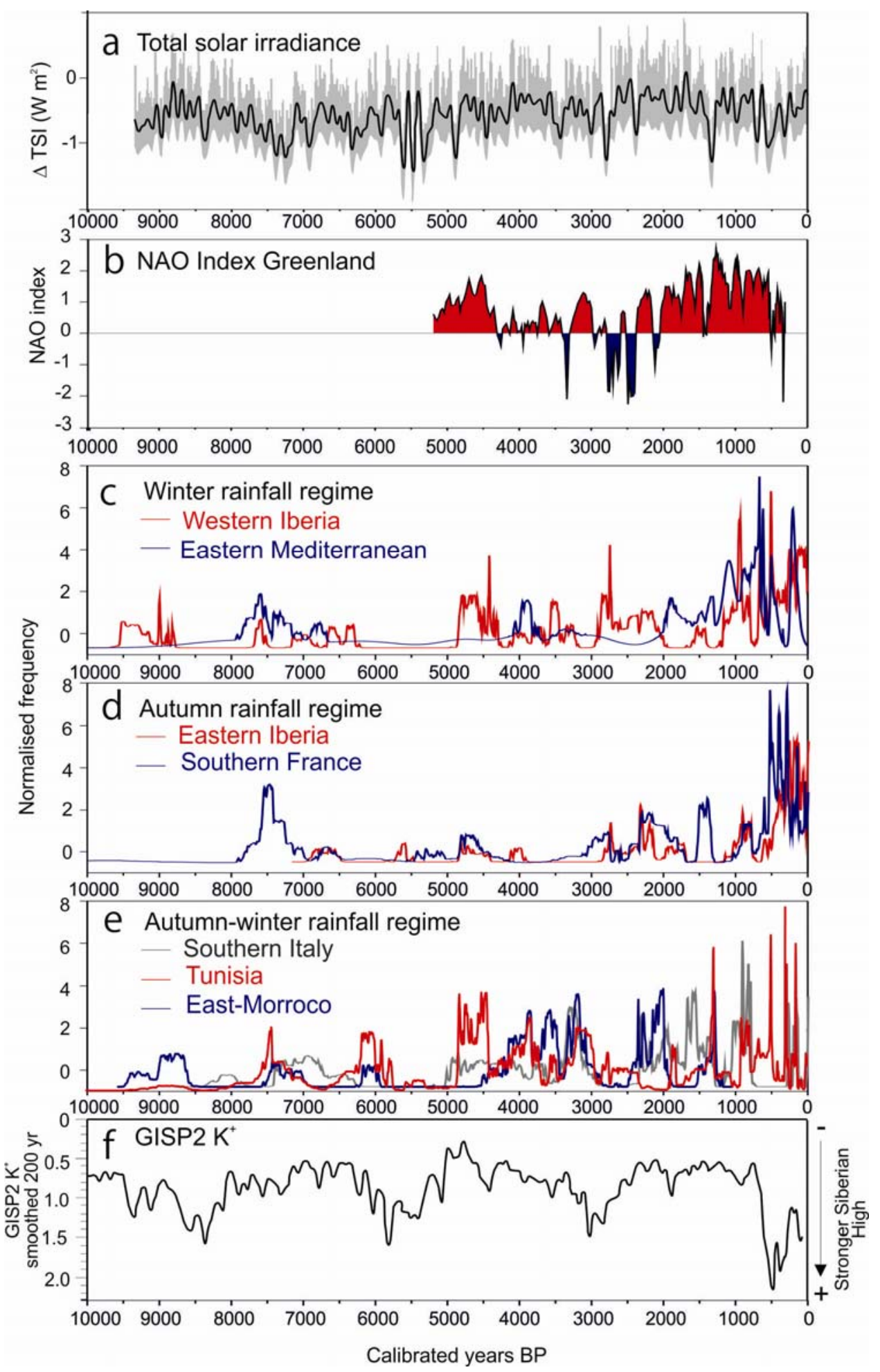

Figure 10. (a) Reconstructed TSI anomalies (100-year lowpass filtered; grey shading: 1 standard deviation uncertainty range) for the past 9300 years (Steinhilber et al., 2009). The reconstruction is based on $10 \mathrm{Be}$ and calibrated using the relationship between instrumental data of the open magnetic field, which modulates the production of $10 \mathrm{Be}$, and TSI for the past four solar minima. Anomalies are relative to the 1976-2006 mean value (1366.14 Wm-2) of Wang et al. (2005). (b) Inferred NAO circulation mode inferred from lake palaeo-redox variability in Greenland (Olsen et al., 2012). (c), (d), (e) Relative CPD plots showing floods and extreme fluvial episodes at different Mediterranean regions. (f) Gaussian smoothed (200 yr) GISP2 potassium (K+; ppb) ion proxy for the Siberian High (Mayewski et al., 1997; Meeker and Mayewski, 2002). 
Recent studies have provided long-term reconstructions of NAO at decadal (Luterbacher et al., 2002), centennial (Trouet et al. 2009) and millennial time scales (Olsen et al., 2012). Late Holocene periods of extreme hydrological events in the northwestern and central Mediterranean (2850-21500, 1500-1400, 1100-800 and 500-300 cal. BP) correspond with predominantly negative phases of NAO as recorded in Greenland (Olsen et al., 2012; Fig. 10b). However, these relationships at centennial time scales should be treated with caution, since some studies have shown that the association between NAO circulation mode and local or regional climate variables has changed over time (Rodó et al., 1997; Goodness and Jones 2002). For instance, the influence of the NAO on temperature variability in southern Europe is extremely sensitive to the position of the NAO action centres (Castro-Díez et al., 2002), which changes from yearto-year (Mächel et al., 1998). In the western and central Mediterranean our metadata analysis has revealed connections between floods and cold pulses that increased arid conditions over Mediterranean North Africa.

Our analysis shows that most of the periods with high flood activity (7400-7100, 48004600 , ca $2750,1500-1400$, ca. 500 cal. BP) match low values of total solar irradiance (Fig. 10). Solar activity minima and large volcanic eruptions show remarkable synchronization with several Holocene cold events (8200, 6300, 4700, 2700, 1550 and 550 cal yrs BP; Wanner et al., 2011; Martín-Puertas et al., 2012). However, the hydrological response to solar activity is still a matter of debate and there may be a strong regional contrast in the occurrence of extreme hydrometeorological events. For instance, periods of high (low) flood activity at multi-decadal scale in the Iberian Peninsula (Benito et al., 2003a, 2004; Vaquero, 2004; Moreno et al., 2008; Corella et al., 2014) and western Alps (Wilhelm et al., 2012) coincide with periods of high (low) total solar irradiance (Delaygue and Bard, 2011). In contrast, periods of high fluvial activity and flooding in Tunisian rivers are associated with solar minima (Vita-Finzi 2008; Fletcher and Zielhofer, 2013).

Our metadata analysis highlights a multi-centennial out-of-phase pattern of extreme events between the western and eastern parts, particularly evident in the contrasting Holocene flood histories of Iberia and the eastern Mediterranean region (Fig. 10). A similar see-saw-like pattern was recognized in lake records during the MCA with drier conditions in the western and wetter conditions in the eastern Mediterranean (Roberts et al., 2012). However, it is the first time that this see-saw pattern has been identified and dated in the Holocene fluvial archive. The spatial characteristics of this hydrological behaviour are in agreement with Dünkeloh and Jacobeit (2003) for coastal Mediterranean precipitation showing a significant negative correlation with the NAO and East Atlantic/Western Russia patterns (Xoplaki et al., 2004), the latter related to the strength of the Siberian High. This negative west-east correlation suggests a mutual influence of atmospheric circulation patterns leading to contrasting precipitation patterns at different time scales. Xoplaki et al. (2004) associated this pattern with a 
predominant meridional circulation linked to a wet northeast Mediterranean and northern Levant correlated with the Polar/Eurasia pattern, as well as a dry Iberian Peninsula (Barnston and Livezey, 1987). This cyclonic anomaly pattern also causes a large-scale cyclonic anomaly circulation over the central and eastern Mediterranean basins and parts of North Africa, producing increased precipitation and temperature in Turkey during winter (Türkeş and Erlat, 2008). Roberts et al. (2012) suggest that similar patterns, with persistent meridional atmospheric circulation, may explain this east-west (wet-dry) hydroclimatic pattern during a 100-year(s) period (LIA at AD 1560-1650). Our meta-data analysis shows that a similar hydroclimatic see-saw pattern is responsible for alternating periods of extreme hydrological events at both ends of the Mediterranean at a multi-centennial time scale, and that such hydroclimatic oscillation was active since at least mid-Holocene.

Northern Hemisphere $(\mathrm{NH})$ atmospheric circulation anomaly patterns may be influenced by westward extension of the Siberian anticyclone. The Siberian High (SH) is a shallow cold-core system that forms in October and persists until April, usually centred over northern Mongolia but during exceptionally high pressures it may extend with a ridge towards southeastern Europe and the Middle East (Lydolf, 1997). Extension of the SH westwards is associated with cooling of the air layer near the ground (Makorgiannis et al., 1981). Rogers (1997) studied North Atlantic storm-track variability and linked cyclogenesis in the Mediterranean with positive anomalies (strong) in the SH. In other words, cold air from the $\mathrm{SH}$ extension mixes with the warmer air over the Mediterranean, creating a surplus of potential energy resulting in cyclogenesis (Makorgiannis et al., 1981). A study comparing a Siberian High index (SHI) with Northern Hemisphere teleconnection patterns (Panagiotopoulos et al. 2005) reveals a correlation statistically significant at the $10 \%$ level of the SH index with other indices such as the Arctic Oscillation (AO), Polar/Euroasian (POL), and West Pacific (WP) patterns. This teleconnection with the AO indicates the influence of the $\mathrm{SH}$ on Northern Hemisphere circulation and, according to temperature patterns, this correlation increases over interdecadal time scales and not on the interannual time scale (Jhun and Lee, 2004). A proxy record of the strength of the SH is obtained from the GISP2 K+ record (Mayewski et al., 1997; Meeker and Mayewski, 2002). The multi-centennial variability of this GISP2 $\mathrm{K}+$ record shows a stronger SH during some Holocene cold periods (e.g. c. 8200, 7300, 2800 cal. BP and LIA). The eastern Mediterranean flood activity shows a positive relation at periods with an increasing trend in the $\mathrm{K}+$ proxy, that is particularly significant during the last $2 \mathrm{ka}$ (e.g. 1900, 600, $150 \mathrm{cal} \mathrm{BP}$; Fig. 10). However, this correlation between flood and high $\mathrm{K}+$ values (strong $\mathrm{SH}$ ) in the eastern Mediterranean is weak during the early and mid-Holocene flood periods. The multi-centennial relationship of fluvial activity and the SH proxy is also significant for Tunisian rivers at some recent periods (3300-2350, 700-200 cal yr BP), which may be explained by enhanced meridional circulation and cyclogenesis during autumn and winter months. 
This analysis shows coherent flood patterns among regions with hydroclimatic links whose variability can be explained in terms of changes in forcing factors (temperature, solar irradiance) and their long-term effects on North Atlantic circulation. However, large scale atmospheric circulation regimes do not control all of the spatial and temporal variability of flood activity in the Mediterranean, as sea-land thermodynamic contrasts and orographic factors also induce intense rainfall events in the Mediterranean (Xoplaki et al., 2004).

\section{Conclusions}

Documentary (since AD 1500) and instrumental (last $100 \mathrm{yrs)} \mathrm{hydrological} \mathrm{data} \mathrm{show}$ that Mediterranean rivers are subject to decadal-scale variations in discharge reflecting changes in atmospheric circulation (Glaser et al., 2010). During the last millennium, particularly in the Late Medieval period and since the $18^{\text {th }}$ Century, this climate signal has been amplified by human disturbance (e.g. deforestation and land use changes) resulting in higher flood discharges and rates of aggradation on floodplains (e.g. Faust et al. 2004, Benito et al., 2008). The last decade has witnessed very significant improvements in our understanding of the controls and chronologies of long-term flood histories in different Mediterranean regions. Although this recent research is beginning to provide robust fluvial chronologies at centennial to millennial time scales, regional coverage is still uneven. Our probability-based analysis reveals that Mediterranean-wide flooding periods (recorded in at least three of the six sub-regions) occurred at 74007150, 4800-4600, 4100-3700, 3300-3200, 2850-2750, 2300-2100, 1700-1600, 1500$1400,950-800$, ca. 300 and 200-100 cal. BP. However, there is significant spatial and temporal variability of Holocene flooding episodes across the Mediterranean, reflecting different flood sensitivity to centennial-scale hydro-climatic changes. Our analysis shows that the temporal distribution of flooding episodes shows similarities in the west and east of Iberian Peninsula and between these regions and southern France and Tunisia. An anti-phase temporal flood pattern was found between the north-western Mediterranean (Iberian Peninsula) and the eastern Mediterranean throughout the Holocene. The central Mediterranean regions may be in-phase or out-of-phase with either the eastern or the western Mediterranean regions. This centennial-to-multicentennial see-saw flood pattern implies that bipolar hydro-climatic conditions operated in the Mediterranean throughout the Holocene. Major periods of Holocene flooding in the north-western Mediterranean region (Iberian Peninsula) correspond with transitions to cooler and wetter conditions (7800-7100, 4800-4500, ca 2750 and ca. 500 cal. BP) associated with low values of total solar irradiance and negative NAO mode. In Tunisia and Morocco, flood periods are associated with a more arid climate and greater hydrological variability (8900-8700, 4200-3500, 3300-3100, 2300-2100 and 1500-1400 cal. BP). Fluvial records in the eastern Mediterranean show an increasing frequency of large floods during wetter periods (7800-7150, 4100-3700, 1900-1600 1200-1100, and 900-600 cal. BP). Over the last 2000 years, flood activity in the eastern Mediterranean 
shows a positive correlation with a strong Siberian High (SH) indicated by the GISP2 K+ proxy (Mayewski et al., 1997; Meeker and Mayewski, 2002).

It is clear that further site-based research is still needed to improve the chronological datasets to better define the flooding episodes in Mediterranean regions and to improve our understanding of their possible forcing factors and the regional response of floods to climate variability. This first probability-based analysis of Holocene ${ }^{14} \mathrm{C}$ and OSL dated fluvial units from across the entire Mediterranean region demonstrates that CPDFs enable fluvial activity periods to be more objectively defined, as well as identifying their hydro-climatic controls. This approach has also demonstrated the value of creating aggregate fluvial-palaeohydrological databases as hydro-climatic proxies, to explain the past and predict the future of floods and droughts in Mediterranean rivers.

\section{Acknowledgements}

This research was funded by the INQUA project "Hydrological EXtreme Events in Changing Climate- HEX Events (1220P)". GB was funded by the Spanish Ministry of Economy and Competitiveness through the research projects CLARIES (ref. CGL201129176), and by the CSIC PIE Intramural Project (ref. 201430E003).

\section{References}

Abbott, J., Valastro, S., 1995. The Holocene alluvial records of the chorai of Metapontum, Basilicata, and Croton, Calabria, Italy. In J. Lewin, M.G. Macklin, and J.C. Woodward, (eds), Mediterranean Quaternary River Environments, Rotterdam, Balkema, 195-205.

Alley, R.B., Mayewski, P.A., Sowers, T., Stuiver, M., Taylor, K.C., Clark, P.U., 1997. Holocene climatic instability: a prominent, widespread event 8200 yr ago, Geology, 25, 483-486.

Alley, R.B., Agustsdottir, A.M., 2005. The 8k event: cause and consequences of a major Holocene abrupt climate change. Quaternary Science Reviews 24, 1123-1149.

Arnaud-Fassetta, G., 2000. Quatre mille ans d'histoire hydrologique dans le delta du Rhône. De l'âge du bronze au siècle du nuclé aire. Grafigéo 11, Collection mémoires et documents de l'UMR PRODIG, Paris.

Arnaud-Fassetta, G., 2002. Geomorphological records of a 'flood dominated regime' in the Rhône Delta (France) between the 1 st century BC and the 2 nd century AD. What correlations with the catchment paleohydrology? Geodinamica Acta 15 (2), 79-92.

Arnaud-Fassetta, G., 2004. The upper Rhône delta sedimentary record in the Arles-Piton core: Analysis of delta-plain subenvironments, avulsion frequency, aggradation rate and origin of sediment yield. Geografiska Annaler 86 A, 367-383.

Arnaud-Fassetta, G., 2007. L'hydrogéomorphologie fluviale, des hauts basins montagnards aux plaines côtières: entre géographie des risques, géarchéologie et géosciences. Habilitation à diriger des recherches (HDR) en géographie physique, université Paris-Diderot (Paris 7), 3 vols.

Arnaud-Fassetta G., Landuré C., 2003. Hydroclimatic hazards, vulnerability of societies and fluvial risk in the Rhone Delta (Mediterranean France) from the Greek period to the Early Middle Ages. In: E. Fouache, Editor, The Mediterranean World Environment and History, Elsevier, Paris, 51-76.

Arnaud-Fassetta, G., Carcaud, N., Castanet, C., Salvador, P.-G., 2010. Fluviatile paleoenvironments in archaeological context: Geographical position, methodological approach and global changeHydrological risk issues. Quaternary International 216, 93-117.

Ballais, J.L., 1995. Alluvial Holocene terraces in eastern Maghreb: climate and anthropogenic controls. In J. Lewin, M.G. Macklin, and J.C. Woodward, (eds), Mediterranean Quaternary River Environments, Rotterdam, Balkema, 183-194.

Barathon, J.J., El Abassi, H., Lechevalier, C., Malek, F., Jolly-Saad, M.C., 2000. Mise au point sur les formations holocènes dans le Rif oriental (Maroc). Géomorphologie: relief, processus, environnement 4, 221-238. 
Bar-Matthews, M., Ayalon, A., Gilmour, M., Matthews, A., Hawkesworth, C.J., 2003. Sealand oxygen isotopic relationships from planktonic foraminifera and speleothems in the Eastern Mediterranean region and their implication for paleorainfall during interglacial intervals. Geochimica et Cosmochimica Acta 67, 3181-3199.

Barnston, A.G., Livezey, R.E., 1987. Classification, seasonality and persistence of low frequency atmospheric circulation patterns. Monthly Weather Review 115, 1083-1126.

Barriendos Vallve, M., Martín-Vide, J., 1998. Secular climatic oscillations as indicated by catastrophic floods in the Spanish Mediterranean coastal area (14th-19th Centuries). Climatic Change 38, 473491.

Bartels, G., Steinmann, S., 1980. Quartärgeomorphologische Untersuchungen im Nordteil der Tunesischen Dosale. Catena 7, 383-405.

Beach, T. P., Luzzadder-Beach, S., 2008. Geoarchaeology and aggradation around Kinet Höyük, an archaeological mound in the Eastern Mediterranean, Turkey. Geomorphology 101, 416-428.

Benito, G., 2003. Palaeohydrological changes in the Mediterranean Region during the Late Quaternary. In: Gregory, K.J. and Benito, G. (Eds.) Palaeohydrology: Understanding Global Change. John Wiley and Sons, Chichester. 123-142.

Benito, G., Machado, M.J., Pérez-González, A., Sopeña, A., 1998. Palaeoflood analysis of the Tagus River (Central Spain). In G. Benito, V.R. Baker and K.J. Gregory (eds.). Palaeohydrology and Environmental Change. John Wiley and Sons, 317-333.

Benito, G., Díez-Herrero, A., Fernández de Villalta, M., 2003b. Magnitude and frequency of flooding in the Tagus basin (Central Spain) over the last millennium. Climatic Change 58, 171-192.

Benito, G., Sopeña, A., Sánchez-Moya, Y., Machado, M.J., Pérez-Gonzalez, A., 2003a. Palaeoflood record of the Tagus River (Central Spain) during the Late Pleistocene and Holocene. Quaternary Science Reviews 22, 1737-1756.

Benito, G., Díez-Herrero, A., de Villalta, M., 2004. Flood response to NAO and Solar Activity in the Tagus Basin (Cental Spain) over the last millennium. Climatic Change, 66, 27-28.

Benito, G., Thorndycraft V.R., Rico M., Sánchez-Moya Y., Sopeña A., 2008. Palaeoflood and floodplain records from Spain: Evidence for long-term climate variability and environmental changes. Geomorphology 101, 68-77.

Benito, G., Rico M., Sánchez-Moya Y. Sopeña, A., Thorndycraft ,V.R, Barriendos, M. 2010. The impact of late Holocene climatic variability and land use change on the flood hydrology of the Guadalentín River, southeast Spain. Global and Planetary Change 70, 53-63.

Benvenuti, M., Mariotti Lippi, M., Pallecchi, P., Sagri, M., 2006. Late-Holocene catastrophic floods in the terminal Arno River (Pisa, Central Italy) from the story of a Roman riverine harbour. The Holocene 16, 863-876.

Berger J.-F., 2003. Les étapes de la morphogenèse holocène dans le sud de la France (Chap. 4). In: S. Van der Leeuw, F. Favory and J.-L. Fiches, (Eds.), Archéologie et systèmes socio-environnementaux. Études multiscalaires sur la vallée du Rhône dans le programme Archaeomedes, CNRS Editions, Sophia-Antipolis, 43-161.

Berger J.-F., Brochier J.L., 2000. Evolution des paysages et des climats dans la moyenne vallée du Rhône et sa bordure préalpine de 13000 à 5000 BP. In : Cupillard, C., and Richard H. (Eds.) Les deniers chausseurs-cuilleurs d'Europe occidentale (13000-5500 av. J.-C.). Actes du Colloque international de Besançon (Doubs, France), 23-25 october 1998, Coll Annales Littéraires l’Université de Franche-Comté, no. 699. «Série Environnement, sociétés et archéologie» no. 1. Presses Universitaires de Franche-Comté, pp. 37-58.

Berger J.-F., Guilaine J., 2009. The 8200 cal BP abrupt environmental change and the Neolithic transition: A Mediterranean perspective. Quaternary International 2009(1-2): 31-49.

Berger, J.-F, Delhon, C., Bonté, S., Thiébault, S, Peyric, D., Beeching, A., Vital, J., 2002. Paléodynamique fluviale, climat, action humaine et evolution des paysages du basin versant de la Citelle (moyenne vallée du Rhône, Drôme) au cours de l'Atlantique ancien (8000-6000 BP) à partir de l'étude de la séquence alluviale d'Espeluche-Lalo. In: Bravard, J.-P., Magny, M. (Eds.), Les fleuves ont une histoire, paléo-environnement des rivières et des lacs français depuis 15000 ans. Errance, Paris, pp. 223-238.

Bicket, A.R., Rendell, H.M., Claridge, A., Rose, P., Andrews, J. Brown, F.S.J., 2009. A multiscale geoarchaeological approach from the Laurentine shore Castelporziano, Lazio, Italy). Géomorphologie: relief, processus, environnement, 4/2009, 241-256.

Boenzi, F., Caldara, M., Capolongo, D., Dellino, P., Piccarreta, M., Simone, O., 2008. Late PleistoceneHolocene landscape evolution in Fossa Bradanica, Basilicata (Southern Italy). Geomorphology 102, 297-306. 
Bond, G., Kromer, B., Beer, J., Muscheler, R., Evans, M.N., Showers, W., Hoffmann, S., Lotti-Bond, R., Hajdas, I., Bonani, G., 2001. Persistent solar influence on North Atlantic climate during the Holocene. Science 294, 2130-2136

Bookman, R., Bartov, Y., Enzel, Y., Stein, M., 2006, The levels of the late Quaternary lakes in the Dead Sea basin: two centuries of research. In: Enzel, Y. Agnon, and M. Stein, (eds.), New Frontiers in Dead Sea Paleoenvironmental Research. Geological Society of America Special Paper 401, p. 155170.

Bookman, R., Enzel, Y., Agnon, A., Stein, M., 2004. Late Holocene lake levels of the Dead Sea. Geological Society of America Bulletin 116, 555-571.

Booth, J., 2010. The Response of Mediterranean Steepland Coastal Catchments to Base Level and Climate Change, Southwestern Crete. Unpublished PhD Thesis, Aberystwyth University.

Bravard, J.-P., Vérot-Bourrély, A., Salvador, P.-G., 1992. Le climat d'après les informations fournies par les sédiments fluviatiles étudiés sur les sites archéologiques. In : M. Magny, H. Richard (ed.), Le climat à la fin de l'Âge de Fer et dans l'Antiquité (500 BC-500 AD). Méthodes d'approches et résultats, Les nouvelles de l'Archéologie 50, 7-13.

Brázdil R., Kundzewicz Z.W., Benito G, Demarée G., Macdonald, N., Roald L.A., 2012. Historical floods in Europe in the past millennium. In: Kundzewicz Z.W. ed. Changes of Flood Risk in Europe IAHS Press and CRC Press/Balkema, IAHS Special Publication 10, pp.121-166.

Bronk Ramsey, C., 2009. Bayesian analysis of radiocarbon dates. Radiocarbon 51, 337-360.

Brückner, H., 1986. Man's impact on the evolution of the physical environment in the Mediterranean Region in historical times. GeoJournal, 13 (1), 7-17.

Bruneton, H., Arnaud-Fassetta, G., Provansal, M., Sistach, D., 2001. Geomorphological evidences for fluvial change during the Roman period in the lower Rhône valley (southern France). Catena 45, 287-312.

Burjachs, F., Giralt, S., Roca, J.R., Seret, G., Julià, R., 1997. Palinología holocénica y desertización en el Mediterráneo occidental. In: Ibáñez, J.J., Valero, B.L., Machado, C. (Eds.), El paisaje mediterráaneo a través del espacio y del tiempo. Implicaciones en la desertificación, Geoforma Editores, Logroño, pp. 379-394

Butzer, K.W., 1980. Holocene alluvial sequences: Problems of dating and correlation. In R.A. Cullingford, D.A. Davidson, and J. Lewin (eds.), Timescales in Geomorphology, John Wiley, Chichester, 131-142.

Butzer, K.W. Miralles, I., Mateu, J.F., 1983. Urban geo-archaeology in Medieval Alzira (Prov. Valencia, Spain). Journal of Archaeological Science, 10, 333-349.

Butzer, K.W., Butzer, E.K., Mateu, J.F., Kraus, P., 1985. Irrigation agrosystems in Eastern Spain: Roman or Islamic origins? Annals, Association of American Geographers 75, 495-522.

Camuffo, D., Enzi, S., 1995. The Analysis of two Bi-millenary Series: Tiber and Po River Floods. In Jones, P.D. Bradley, R.S. and Jouzel, J., editors, Climatic Variations and Forcing Mechanisms of the last 2000 years. NATO ASI Series, Series I: Global Environmental Change, Vol. 41, Stuttgart: Springer Verlag, 433-450.

Carcaillet, J., Mugnier, J. L., Koçi, R., Jouanne, F., 2009. Uplift and active tectonics of southern Albania inferred from incision of alluvial terraces. Quaternary Research, 71, 465-476.

Carmona, P., Dupré, M., Belluomini, G., 1994. Coastal changes in the Gulf of Valencia (Spain) during the subatlantic period. Quaternaire 5, 49-57.

Carmona, P., Ruiz, J.M., 2011. Historical morphogenesis of the Turia River coastal floodplain in the Mediterranean littoral of Spain. Catena 86, 139-149.

Carrión, J.S., 2002. Patterns and processes of Late Quaternary environmental change in a montane region of southwestern Europe, Quaternary Sci. Rev., 21, 2047-2066.

Carrión, J.S., Fernández, S., Jiménez-Moreno, G., Fauquette, S., Gil-Romera, G., González-Sampériz, P., Finlayson, C., 2010. The historical origins of aridity and vegetation degradation in southeastern Spain. Journal of Arid Environments 74, 731-736.

Casana, J., 2008. Mediterranean valleys revisited: Linking soil erosion, land use and climate variability in the Northern Levant. Geomorphology, 101, 429-442.

Castro-Díez, Y., Pozo-Vazquez, D., Rodrigo, F.S., Esteban-Parra, M.J., 2002. NAO and winter temperature variability in southern Europe. Geophysical Research Letters 29, 8, 1-4.

Cheddadi, R., Yu, G., Guiot, J., Harrison, S.P., Prentice, I.C., 1997. The climate of Europe 6000 years ago. Climate Dynamics 13, 1-9.

Conte, M., Giuffrida, S., Tedesco, S., 1989. The Mediterranean Oscillation: Impact on Precipitation and Hydrology in Italy, Conference on Climate and Water. Academy of Finland, pp. 121-137. 
Corella J.P., Benito G., Rodriguez-Lloveras X., Brauer, A., Valero-Garcés, B.L., 2014. Annually-resolved lake record of extreme hydro-meteorological events since AD 1374 in NE Iberian Peninsula. Quaternary Science Reviews 93, 77-90

Corte-Real, J., Zhang, X., Wang, X., 1995. Large-scale circulation regimes and surface climatic anomalies over the Mediterranean. International Journal of Climatology 15, 1135-1150.

Cortés Sánchez M., Jiménez Espejo F.J., Simón Vallejo M.D., Gibaja Bao J.F., Carvalho A.F., MartínezRuiz F., et al. 2012. The Mesolithic-Neolithic transition in southern Iberia. Quaternary Research 77, 221-34.

Cotecchia, V., Dai Pra, G., Magri, G., 1969. Oscillazioni tirreniane ed oloceniche del livello mare nel golfo di Taranto, corredate da datazioni col metodo del radiocarbonio. Geología Applicata e Idrogeología 4, 93-148.

Cremaschi, M., Gasperi, G., 1989. L'alluvione alto-medioevale di Mutina (Modena) in rapporto alle variazioni climatiche oloceniche. Memorie Societa Geologica Italiana 42, 179-90. D'Amato, S. 1980: II primo prosciugamento del Fucino. Avezza

Cremonini, S., Labate, D., Curina, R., 2013. The late-antiquity environmental crisis in Emilia region (Po river plain, Northern Italy): Geoarchaeological evidence and paleoclimatic considerations. Quaternary International 316, 162-178.

Davis, B.A.S., Brewer, S., Stevenson, A. C., Guiot, J., et al., 2003. The temperature of Europe during the Holocene reconstructed from pollen data, Quaternary Science Reviews, 22 (15-17), 1701-1716.

Deckers, K. 2005. Post-Roman History of River Systems in Western Cyprus: Causes and Archaeological Implications. Journal of Mediterranean Archaeology, 18, 155-181.

Delaygue G. \& E. Bard, 2011. An Antarctic view of Beryllium-10 and solar activity for the past millennium. Climate Dynamics, vol. 36, 11-12, p.2201-2218, doi:10.1007/s00382-010-0795-1.

Dorado, M., Valdeolmillos, A., Ruiz, M.B., Gil, M.J., Bustamente, I., 2002. Climatic changes since the Late-glacial/Holocene transition in La Mancha Plain (South-central Iberian Peninsula, Spain) and their incidence on Las Tablas de Daimiel marshlands. Quaternary International 93-94, 73-84.

Dünkeloh, A., Jacobeit, J., 2003. Circulation dynamics of Mediterranean precipitation variability 194898. International Journal of Climatology 23, 1843-1866.

El Amrani, M., Macaire, J.J., Zarki, H., Bréhéret, J.G., Fontugne, M. 2008. Contrasted morphosedimentary activity of the lower Kert River (northeastern Morocco) during the Late Pleistocene and the Holocene. C.R. Geoscience 340, 533-542.

Ely, L.L., 1997. Response of extreme floods in the southwestern United States to climatic variations in the late Holocene. Geomorphology 19, 175-201.

Enzel, Y., Revital Bookman (Ken Tor), Sharon, D., Gvirtzman, H., Dayan, U., Ziv, B., Stein, M., 2003. Late Holocene climates of the Near East deduced from Dead Sea level variations and modern regional winter rainfall, Quaternary Research, Volume 60, Issue 3, November, Pages 263-273.

Enzel, Y., Bookman R., Sharon, D., Gvirtzman, H., Dayan, U., Ziv, B., Stein, M. 2003. Late Holocene climates of the Near East deduced from Dead Sea level variations and modern regional winter rainfall Quaternary Research 60, 263-273.

Faust, D., Zielhofer, C., Baena, R., Diaz del Olmo, F., 2004. High-resolution fluvial record of late Holocene geomorphic change in northern Tunisia: climatic or human impact? Quaternary Science Reviews 23, 1757-1775.

Fletcher, W.J., Sánchez Goñi, M.F., 2008. Orbital- and sub-orbital-scale climate impacts on vegetation of the Western Mediterranean basin over the last 48,000 yr. Quaternary Research, 70(3): 451-464.

Fletcher, W.J., Zielhofer, C., 2013. Fragility of Western Mediterranean landscapes during Holocene Rapid Climate Changes. Catena 103, 16-29.

Fuchs, M., Lang, A. 2001. OSL dating of coarse-grain fluvial quartz using single-aliquot protocols on sediments from NE Peloponnese, Greece. Quaternary Science Reviews, 20, 783-787.

Fuchs, M., Wagner, G. A. 2003. Recognition of insufficient bleaching by small aliquots of quartz for reconstructing soil erosion in Greece. Quaternary Science Reviews, 22, 1161-1167.

Fuchs, M., Wagner, G. A. 2005. The chronostratigraphy and geoarchaeological significance of an alluvial geoarchive: Comparative OSL and $\mathrm{AMS}^{14} \mathrm{c}$ dating from Greece. Archaeometry, 47, 849-860.

Fuller, I.C., Macklin, M.G., Passmore, D.G., Brewer, P.A., Lewin, J., Wintle, A.G., 1996. Geochronologies and environmental records of Quaternary fluvial sequences in the Guadalope basin, northeast Spain, based on luminescence dating. In Branson, J., Brown, A.G. and Gregory, K.J. (eds.), Global Continental Changes: the context of Palaeohydrology, Geological Society of London, Special Publication $\mathrm{n}^{\circ} 115$, London, 99-120.

Garcia-Garcia, F., Bohorquez, P., Martínez-Sanchez, C., Perez-Valera, F., Perez-Valera, L.A., Calero, J.A., Sánchez-Gómez, M., 2013. Stratigraphic architecture and alluvial geoarchaeology of an 
ephemeral fluvial infilling: Climatic versus anthropogenic factors controlling the Holocene fluvial evolution in southeastern Spain drylands. Catena 104, 272-279.

Gasse, F., 2000. Hydrological changes in the African tropics since the Last Glacial Maximum. Quaternary Science Reviews 19, 189-211.

Gat, J.R., Magaritz, M., 1980. Climatic variation in the eastern Mediterranean Sea area. Naturuissenschaften, 67, 80-87.

Genty, D., Blamart, D., Ghaleb, B., Plagnes, V., Causse, C., Bakalowicz, M., Zouari, K., Chkir, N., Hellstrom, J., Wainer, K., Bourges, F., 2006. Timing and dynamics of the last deglaciation from European and North African $\triangle 13 \mathrm{C}$ stalagmite profiles - comparison with Chinese and South Hemisphere stalagmites. Quaternary Science Reviews 25, 2118-2142.

Giraudi, C., 1998. Late Pleistocene and Holocene lake level variations in Fucino Lake (Abruzzo - Central Italy) inferred from geological, archaeological and historical data. ESF Workshop 'Palaeohydrology as reflected in lake-level changes as climatic evidence for Holocene times'. Palaoklimaforschung, Palaeoclimate Research 25, 1-17.

Giraudi, C., 2005. Late-Holocene alluvial events in the Central Apennines, Italy. The Holocene 15, 768773.

Giraudi, C., Magny, M., Zanchetta, G., and Drysdale, R. N., 2011. The Holocene climatic evolution of the Mediterranean Italy: a review of the geological continental data, The Holocene, 21, 105-117.

Glaser, R., Riemann, D., Schoenbein, J., Barriendos, M., Brázdil, R, Bertolin, C., Camuffo, D., Deutsch, M., Dobrovolny, P., van Engelen, A., Enzi, S., Halickova, M., Koenig, S.J., Kotyza, O., Limanowka, D., Mackova, J., Sghedoni, M., Martin, B., Himmelsbach, I., 2010. The variability of European floods since AD 1500. Climatic Change 101, 235-256.

Goldberg, P., 1984. Late Quaternary history of Qadesh Barnea, northeastern Sinai. Zeitschrift für Geomorphologie, 28, 193-217.

González-Sampériz, P., Utrilla, P., Mazo, C., Valero-Garcés, B., Sopeña, M.C., Morellón, M., Sebastián, M., Moreno, A., Martínez Bea, M., 2009. Patterns of human occupation during the early Holocene in the Central Ebro Basin (NE Spain) in response to the $8.2 \mathrm{ka}$ climatic event. Quaternary Research 71, 121-132.

González-Sampériz, P., Valero-Garcés, B.L., Moreno, A., Jalut, G., García-Ruiz, J.M., Martí-Bono, C., Delgado-Huertas, A., Navas, A., Otto, T., Dedoubat, J.J., 2006. Climate variability in the Spanish Pyrenees during the last 30,000 yr revealed by the El Portalet sequence. Quaternary Research 66, 38-52.

Goodess, C.M., Jones, P.D., 2002. Links between circulation and changes in the characteristics of Iberian rainfall. International Journal of Climatology 22, 1593-1615.

Greenbaum, N., Ben-Zvi, A., Haviv, I., Enzel, Y., 2006, The hydrology and paleohydrology of tributaries to the Dead Sea. In: Enzel, Y. Agnon, and M. Stein, (eds.), New Frontiers in Dead Sea Paleoenvironmental Research. Geological Society of America Special Paper 401, p. 63-94.

Greenbaum, N., Schick, A.P., Baker, V.R., 2000. The palaeoflood record of a hyperarid catchment, Nahal Zin, Negev Desert, Israel. Earth Surface Processes and Landforms, 25, 951-971.

Gregory, K.J., Benito, G., Dikau, R., Golosov, V., Johnstone, E., Jones, A.J.J., Macklin, M.G., Parsons, A.J., Passmore, D.G., Poesen, J., Soja, R., Starkel, L., Thorndycraft, V.R., Walling, D.E., 2006. Past hydrological events and global change. Hydrological Processes, 20, 199-204.

Guilbert, X., 1994. Les crues de la Durance depuis le XIVème siècle. Fréquence, périodicité et interprétation paléo-climatique. Mémoire de maîtrise de Géographie. Université d'Aix-Marseille I, Aix-en-Provence, $350 \mathrm{p}$.

Harding, A., Palutikof, J., Holt, T., 2009. The climate system. In: J. Woodward (ed.), The Physical Geography of the Mediterranean. Oxford University Press, Oxford, 69-88.

Hassan, F., 1997. Holocene palaeoclimates of Africa. African Archaeological Review 14, 213-230.

Hoffmann, T., Lang, A., Dikau, R., 2008. Holocene river activity: analysing 14C-dated fluvial and colluvial sediments from Germany. Quaternary Science Reviews 27, 2031-2040.

Ibouhouten, H., Zielhofer, C., Mahjoubi, R., Kamel, S., Linstädter, J., Mikdad, A., Bussmann, J., Werner, P., Härtling, J., Fenech, K., 2010. Archives alluviales holocènes et occupation humaine en Basse Moulouya (Maroc nord-oriental). Géomorphologie : relief, processus, environnement 2010/1, 41-56.

Jaccard P. 1908. Nouvelles recherches sur la distribution florale. Bull. Soc. Vaudoise Sci. Nat. 44:223270.

Jalut, G., Deboubat, J. J., Fontugne, M., Otto, T., 2009: Holocene circum-Mediterranean vegetation changes: climate forcing and human impact, Quaternary Int. 200, 4-18.

Jalut, G., Esteban Amat, A., Bonnet, L., Gauquelin, T., Fontugne, M., 2000. Holocene climatic changes in the Western Mediterranean, from south-east France to south-east Spain. Palaeogeography, Palaeoclimatology, Palaeoecology, 160, 255-290. 
Jhun, J.G., Lee, E.J., 2004. A new East Asian winter monsoon index and associated characteristics of the winter monsoon. J. Climate, 17, 711-726.

Jing, Z., Rapp, G. 2003. The coastal evolution of the Ambracian Embayment and its relationship to archaeological settings. In Wiseman, J. and Zachos, K. L. (Eds.) Landscape archaeology in southern Epirus, Greece. Athens, American School of Classical Studies at Athens.

Jorda, M., Provansal, M., 1996. Impacts de l'anthropisation et du climat sur le détritisme en France du sud-est (Alpes du sud et Provence). Bulletin de la Société Géologique de France, 167, (1), 159-168.

Jorda, M., Miramont, C., Rosique, T., Sivan, O., 2002. Evolution de l'hydrosystème durancien (Alpes du Sud, France) depuis la fin du Pléniglaciaire supérieur. In: Bravard, J.-P., Magny, M. (Eds.), Les fleuves ont une histoire, paléo-environnement des rivières et des lacs français depuis 15000 ans. Errance, Paris, pp. 239-249.

Jorda, M., Parron, C. Provansal, M., Roux, M., 1991. Erosion et détritisme holocènes en Basse Provence calcaire. L'impact de l'anthropisation. Physio-Géo, 22/23, 37-47.

Knox, J.C., 2000. Sensitivity of modern and Holocene floods to climate change. Quaternary Science Reviews 19, 439-457.

Koukouvelas, I. K., Stamatopoulos, L., Katsonopoulou, D., Pavlides, S., 2001. A palaeoseismological and geoarchaeological investigation of the Eliki fault, Gulf of Corinth, Greece. Journal of Structural Geology, 23, 531-543.

Leira, M., Santos, L., 2002. An early Holocene short climatic event in the northwestIberian Peninsula inferred from pollen and diatoms. Quaternary International93-94, 3-12.

Lespez, L. 2003. Geomorphic responses to long-term land use changes in Eastern Macedonia (Greece). Catena, 51, 181-208.

Linstädter, A., Zielhofer, C., 2010. Regional fire history shows abrupt responses of Mediterranean ecosystems to centennial-scale climate change (Olea-Pistacia woodlands, NE Morocco). Journal of Arid Environments 74, 101-110.

Lionello, P., Galati, M.B., 2008. Links of the significant wave height distribution in the Mediterranean Sea with the north hemisphere teleconnection patterns. Adv. Geosci. 17, 13-18.

Lionello, P., Malanotte-Rizzoli, P., Boscolo, R., 2006. The Mediterranean Climate: An Overview of the Main Characteristics and Issues. Elsevier, Netherlands.

Littmam, T., 2000. An empirical classification of weather types in the Mediterranean Basin and their interrelation with rainfall. Theor. Appl. Climatol. 66, 161-171.

Llasat, M.C., Barriendos, M., Barrera, A., Rigo, T., 2005. Floods in Catalonia (NE Spain) since the 14th century. Climatological and meteorological aspects from historical documentary sources and old instrumental records. Journal of Hydrology 313, 32-47.

Llasat, M.C., Puigcerver, M., 1990. Cold air pools over Europe. Met. Atmos. Physics 42, 171-177.

López-Avilés, A., Ashworth, P.J., Macklin, M.G., 1998. Floods and Quaternary sedimentation styles in a bedrock controlled reach of the Bergantes river, Ebro basin, northeast Spain. In Benito, G., Baker, V.R. and Gregory, K.J. (Eds), Palaeohydrology and environmental change, John Wiley and Sons Chichester, 182-196.

Luterbacher J., García-Herrera R., Allan A. R., Alvarez-Castro B.G., Benito G., Booth J., Büntgen U., Colombaroli D., Davis B., Esper J., Felis T., Fleitmann D., Frank D., Gallego D., Gonzalez-Rouco F.J., Goosse H., Kiefer T., Macklin M.G., Montagna P., Newman L., Power M.J., Rath V., Ribera P., Roberts N., Silenzi S., Tinner W., Valero-Garcés B., van der Schrier G., Vannière B., Wanner H., Werner J.P., Willett G., Xoplaki E., Zerefos C.S., Zorita E., 2012. A review of 2000 years of paleoclimatic evidence in the Mediterranean. In: P. Lionello (Ed.), The Climate of the Mediterranean Region: From the Past to the Future. Elsevier, London, pp. 87-185. DOI: 10.1016/B978-0-12-416042-2.00002-1

Luterbacher, J., Xoplaki, E., Dietrich, D., Jones, P.D., Davies, T.D., Portis, D., Gonzalez-Rouco, J.F., von Storch, H., Gyalistras, D., Casty, C., Wanner, H., 2002. Extending North Atlantic Oscillation Reconstructions Back to 1500. Atmos. Sci. Lett., 2, 114-124 (doi:10.1006/asle.2001.0044).

Lydolf, P.E., 1977. Climates of the Soviet Union. Elsevier, 443 pp.

Maas, G.S., 1998. River Response to Quaternary Environmental Change, Southwestern Crete, Greece. Ph.D. Thesis, School of Geography. University of Leeds.

Maas, G.S., Macklin, M.G., Kirkby, M.J., 1998. Late Pleistocene and Holocene River Development in Mediterranean Steepland Environments, Southwest Crete, Greece. In Benito, G., Baker, V.R. and Gregory, K.J. (Eds.) Palaeohydrology and Environmental Change. Chichester, Wiley, 153-165.

Maas, G.S., Macklin, M.G., 2002. The impact of recent climate change on flooding and sediment supply within a Mediterranean mountain catchment, southwestern Crete, Greece. Earth Surface Processes and Landforms 27, 1087-1105. 
Machado M.J., Benito G., Rico M.T., Sánchez-Moya Y., Sopeña A., 2012. Controles climáticos y ambientales en los registros de paleocrecidas de la Rambla de la Viuda (Castellón). In: A. GonzálezDíez, A. (eds), Avances de la Geomorfología en España 2010-2012 PubliCan Ediciones: 437-444, Santander.

Machado, M.J., Benito, G., Barriendo, M., Rodrigo, F.S., 2011. 500 years of rainfall variability and extreme hydrological events in Southeastern Spain drylands. Journal of Arid Environments 75, 1244-1253. doi: 10.1016/j.jaridenv.2011.02.002.

Mächel, H., Kapala, A., Flohn, H., 1998. Behavior of the centers of action above the Atlantic since 1881. Part I: Characteristics of seasonal and interannual variability. Int. J. Climatol. 18, 1-22.

Macklin, M.G., Benito, G., Gregory, K.J., Johnstone, E., Lewin, J., Soja, R., Starkel, L., Thorndycraft, V.R., 2006. Past hydrological events reflected in the Holocene fluvial history of Europe. Catena 66, 145-154.

Macklin, M.G., Fuller, I.C., Jones, A.F., Bebbington, M., 2012. New Zealand and UK Holocene flooding demonstrates interhemispheric climate asynchrony. Geology, 40(9), 775-778.

Macklin, M.G., Lewin, J., Woodward, J.C., 1995. Quaternary fluvial systems in the Mediterranean basin. In J. Lewin, M.G. Macklin, and J.C. Woodward, (eds), Mediterranean Quaternary River Environments, Rotterdam, Balkema, 1-25.

Macklin, M.G., Lewin, J., 2003. River sediments, great floods and centennial-scale Holocene climate change. Journal of Quaternary Science 18, 101-105.

Macklin, M.G., Passmore, D.G., Stevenson, A.C., Davis, B.A., Benavente, J.A., 1994. Responses of rivers and lakes to Holocene environmental change in the Alcañiz region, Teruel, north-east Spain. In A.C. Millington and K. Pye (eds.) Environmental Change in Drylands: Biogeographical and Geomorphological Perspectives, John Wiley, Chichester. 113-130.

Macklin, M.G., Tooth, S., Brewer, P.A., Noble, P.L., Duller, G.A.T., 2010. Holocene flooding and river development in a Mediterranean steepland catchment: the Anapodaris Gorge, south-central Crete, Greece. Global and Planetary Change, 70, 35-52.

Macklin, M.G., Woodward, J. C., 2009. River systems and environmental change. In: J. Woodward (ed.), The Physical Geography of the Mediterranean. Oxford University Press, Oxford, 319-352.

Magny, M., 2004. Holocene climatic variability as reflected by mid-European lake-level fluctuations, and its probable impact on prehistoric human settlements. Quaternary International 113, 65-80.

Magny, M., de Beaulieu, J.L., Drescher-Schneider, R., Vannière, B., Walter-Simonnet, A. V., Miras, Y., Millet, L., Bossuet, G., Peyron, O., Brugiapaglia, E., Leroux, A. 2007. Holocene climate changes in the central Mediterranean as recorded by lake-level fluctuations at Lake Accesa (Tuscany, Italy), Quaternary Sci. Rev., 26, 1736-1758, 2007.

Magny, M., Vannière, B., Zanchetta, G., Fouache, E., Touchais, G., Petrika, L., Coussot, C., WalterSimonnet, A. V., Arnaud, F., 2009: Possible complexity of the climatic event around 4300-3800 cal BP in the central and western Mediterranean, The Holocene, 19, 823-833.

Magny, M., Vannière, B., Calo, C., Millet, L., Leroux, A., Peyron, O., Zanchetta, G., La Mantia, T., Tinner, W., 2011. Holocene hydrological changes in south-western Mediterranean as recorded by lake-level fluctuations at Lago Preola, a coastal lake in southern Sicily, Italy, Quaternary Sci. Rev., 30, 2459-2475.

Magri, D., Parra, I., 2002. Late Quaternary western Mediterranean pollen records in African winds. Earth and Planetary Science Letters 200, 401-408.

Makorgiannis, T. J. Giles, B. D., Flocas A. A., 1981. The Problem of the Extension of the Siberian Anticyclone Towards Southeast Europe, and Its Relation to Atmospheric Circulation Anomalies over the Northern Hemisphere. Arch. Met. Geoph. Biokl., Set. A, 30, 185-196.

Mariotti-Lippi, M., Bellini, C., Trinci, C., Benvenuti, M., Pallecchi, P., Sagri, M., 2007. Pollen analysis of the ship site of Pisa San Rossore (Tuscany, Italy): the implication for catastrophic hydrological events and climatic change during the late Holocene. Vegetation History Archaeobotany 16, 453465.

Martín-Puertas, C., Matthes, K., Brauer, A., Muscheler, R., Hansen, F., Petrick, C., Aldahan, A., Possnert, G., van Geel, B., 2012. Regional atmospheric circulation shifts induced by a grand solar minimum. Nature Geosciences 5, 397-401.

Martín-Puertas, C., Valero, B.L., Brauer, A., Mata, M.P., Delgado-Huertas, A., Dulski, P., 2009. The Iberian-Roman Humid Period (2600-2100 cal yr BP) in the Zóñar Lake varve record (Andalucía, southern Spain). Quaternary Research 71, 108-120.

Mayewski, P.A., Meeker, L.D., Twickler, M.S., Whitlow, S., Yang, Q., Lyons, W.B., Prentice, M., 1997. Major features and forcing of high- latitude northern hemisphere atmospheric circulation using a 110,000-year long glaciochemical series. Journal of Geophysical Research 102, 26345- 26366. 
Meeker, L.D., Mayewski, P.A., 2002. A 1400-year high-resolution record of atmospheric circulation over the North Atlantic and Asia. Holocene 12, 257-266.

Migowski, C., Stein, M., Prasad, S., Negendank, J.F.W., Agnon, A., 2006. Holocene climate variability and cultural evolution in the Near East from the Dead Sea sedimentary record. Quaternary Research 66, 421-431.

Miramont C., Belingard C., Edouard J.-L., Jorda M., 1999. Reconstitution des paléoenvironnements holocènes alpins et préalpins. Evaluation des paramètres climatiques et anthropiques responsables de l'évolution, Univ. Prahist. Archaol. 55, 189-196.

Miramont, C., 1998. Morphogenèse, activité érosive et détritisme alluvial holocènes dans le bassin de la moyenne Durance. Ph.D thesis in geography, univ. Aix- Marseille 1.

Molle, H.G., 1979. Untersuchungen zur Entwicklung der vorzeitlichen Morphodynamik im TibestiGebirge (Zentralsahara) und in Tunesien. Berliner Geographische Abhandlungen 25, 96 p.

Morellón, M., Valero-Garcés, B., Moreno, A., González-Sampériz, P., Mata, P., Romero, O., Maestro, M., Navas, A., 2008. Holocene palaeohydrology and climate variability in Northeastern Spain: The sedimentary record of Lake Estanya (Pre-Pyrenean range). Quaternary International 181, 15-31.

Moreno, A., Valero-Garcés, B.L., González-Sampériz, P., Rico, M., 2008. Flood response to rainfall variability during the last 2000 years inferred from the Taravilla Lake record (Central Iberian Range, Spain). Journal of Paleolimnology 40, 943-961.

Neboit, R., 1983. L'homme et l'érosion. Faculté des lettres et sciences humaines de l'Université de Clermont-Ferrand II, fasc. 17, Clermont-Ferrand, p. 183.

Neboit, R., 1984. Genèse des terrasses fluviatiles holocènes en Sicile et en Italie Méridionale. Bulletin de l'Association française pour l'étude du Quaternaire, 1.2.3., 157-160.

Noble, P.L., 2004. Response of a Steepland River System to Late Quaternary Environmental Change, South Central Crete. Unpublished PhD Thesis, University of Wales, Aberystwyth.

Olsen, J., Anderson, N.J., Knudsen, M.J., 2012. Variability of the North Atlantic Oscillation over the past 5,200 years. Nature Geoscience 5, 808-812.

Ortega, J.A., Garzón., G., 2009. A contribution to improved flood magnitude estimation in base of palaeoflood record and climatic implications. Guadiana River (Iberian Peninsula). Natural Hazards and Earth System Sciences, 9, 229-239

Ortega, J.A., Garzón, G., 2004. Influencia de la oscilación del Atlántico norte en las inundaciones del Río Guadiana. In: Benito, G., Díez Herrero, A. (Eds.), Riesgos naturales y antrópicos en Geomorfología. CSIC, Madrid, pp.117-126.

Panagiotopoulos, F., Shahgedanova, M., Hannachi, A.B.A., Stephenson, D.B., 2005. Observed trends and teleconnections of the Siberian high: A recently declining center of action. Journal of Climate, 18 (9). pp. 1411-1422. ISSN 1520-0442

Pardé, M., 1950. Sur les régimes fluviaux méditerranées. Comptes Rendus du Congrès International de Geógraphie, Union Géographique Internationale. Lisbonne 1949. Tome II. 391-420.

Pavlides, S. B., Koukouvelas, I. K., Kokkalas, S., Stamatopoulos, L., Keramydas, D., Tsodoulos, I., 2004. Late Holocene evolution of the East Eliki fault, Gulf of Corinth (Central Greece). Quaternary International, 115-116, 139-154.

Piccarreta M., Caldara, M., Capolongo, D., Boenzi F., 2011. Holocene geomorphic activity related to climatic change and human impact in Basilicata, Southern Italy. Geomorphology 128, 137-147.

Piervitali, E. \& Colacino, M., 2003. Precipitation scenarios in the Central-Western Mediterranean Basin. In: H. J. Bolle (Ed.). Mediterranean Climate. Springer Verlag, Berlin, 245-258.

Pope, R.J.J., Wilkinson, K.N., 2006. Reconciling the roles of climate and tectonics in Late Quaternary fan development on the Spartan piedmont: new evidence from field mapping, soil analysis and thermoluminescence dating. In Harvey, A. M., Mather, A. E. and Stokes, M. (Eds.) Alluvial fans, geomorphology, sedimentology and dynamics. Geological Society Special Publication.

Provansal, M., Berger, J.F., Bravard, J.-P., Salvador, P.G., Arnaud-Fassetta, G., Bruneton, H., VerotBourrely, A., 1999. Le régime du Rhône dans l'Antiquité et au Haut Moyen-Age. Gallia 56, 13-32.

Provansal, M., Bruneton, Hl, Vella, C., Arnaud-Fassetta, G., Ballais, J.-L., Leveau, P., 2002. Paléohydrologie holocène dans la basse vallée du Rhône, d'Orange à la mer. In: Bravard, J.-P., Magny, M. (Eds.), Les fleuves ont une histoire, paléo-environnement des rivières et des lacs français depuis 15000 ans. Errance, Paris, pp. 251-258.

Psuty, N., 2008. The Coastal Foredune: A Morphological Basis for Regional Coastal Dune Development. In Martínez M.L., Psuty N.P. (Ed.), Coastal Dunes. Ecology and Conservation. Springer, New York, 11-27.

Ramrath, A., Sadori, L. and Negendank, F.W. 2000: Sediments from Lago di Mezzano, central Italy: a record of Lateglacial-Holocene climatic variations and anthropogenic impact. The Holocene 10, 8795. 
Redmond, K.T., Enzel, Y., House, P.K. Biondi, F., 2002. Climate variability and flood frequency at decadal to millennial time scales. In: House, P.K., Webb, R.H., Baker, V.R., Levish, D.R. (Eds.), Ancient Floods, Modern Hazards: Principles and Applications of Paleoflood Hydrology. Water Science and Application Series, Vol. 5, American Geophysical Union, Washington, DC, pp. 21-45.

Rico, M.T., 2004. Las paleocrecidas en la cuenca media del río Segre durante el Pleistoceno SuperiorHoloceno: registros morfosedimentarios y análisis hidrológico. $\mathrm{PhD}$ dissertation, University of Zaragoza.

Risebrobakken, B., Jansen, E., Andersson, C., Mjelde, E., Hevrøy, K., 2003. A high-resolution study of Holocene paleoclimatic and paleoceanographic changes in the Nordic Seas. Paleoceanography 18, 1017. doi:10.1029/2002PA000764.

Roberts, N., Moreno, A., Valero-Garcés, B. L., Corella, J. P., Jones, M., Allcock, S., Woodbridge, J., Morellon, M., Luterbacher, J., Xoplaki, E., Türkes, M., 2012. Palaeolimnological evidence for an east-west climate see-saw in the Mediterranean since AD 900, Global Planet. Change, 84-85, 2334.

Roca, J.R., Juliá, R., 1997. Late-glacial and Holocene lacustrine evolution based on ostracode assemblages in Southeastern Spain. Geobios 30 (6), 823-830.

Rodó, X., Baert, E., Comin, F.A., 1997. Variations in seasonal rainfall in southern Europe during the present century: Relationships with the North Atlantic oscillation and the El Niño-Southern Oscillation. Climate Dynamics 13, 275-284.

Rogers, J.C., 1997, North Atlantic storm track variability and its association to the North Atlantic Oscillation and climate variability of northern Europe. J. Climate, 10, 1635-1647.

Rumsby, B.T., Macklin, M.G. 1994. Channel and floodplain response to recent abrupt climate change: the Tyne basin, northern England. Earth Surface Processes and Landforms, 19, 499-515.

Salgueiro, R., Machado, M.J., Barriendos, M., Pereira, H., Benito G. 2013. Flood magnitudes in the Tagus River (Iberian Peninsula) and its stochastic relationship with daily North Atlantic Oscillation since mid-19th Century. Journal of Hydrology, 502, 191-201

Salvador P.-G., Vérot-Bourrély A., Bravard J.-P., Franc O., Macé S., 2002. Les crues du Rhône à l'époque gallo-romaine dans la région lyonnaise. In: J.-P. Bravard and M. Magny, (Eds), Histoire des rivières et des lacs de Lascaux à nos jours, Errance, Paris, pp. 215-221

Salvador, P.-G., Berger, J.-F., Fontugne, M., Gauthier, E., 2005. Etude des enregistrements sédimentaires holocènes des paléoméandres du Rhône dans le secteur des Basses Terres (Ain, Isère, France). Quaternaire 16, 315-328.

Sancho, C., Peña, J.L., Muñoz, A., Benito, G., McDonald, E., Rhodes, E.J., Longares, L.A., 2008. Holocene alluvial morphopedosedimentary record and environmental changes in the Bardenas Reales Natural Park (NE Spain). Catena 73, 225-238.

Santos, L., Vidal Ramoni, J.R., Jalut, G., 2000. History of vegetation during the Holocene in the Courel and Queixa Sierras, Galicia, northwest Iberian Peninsula. Journal of Quaternary Science 15, 621632.

Scharpenseel, H.W., Schiffmann, H., 1985: Natürliche Radiokohlenstoffmessungen als Beitrag zur Definition rezent- oder paläoklimatischer Leithorizonte in Tunesien. Zeitschrift für Pflanzenernährung und Bedenkunde 148, 113-130.

Scharpenseel, H.W., Zakosek, H., 1979. Phasen der Bodenbildung in Tunesien. Zeitschrift für Geomorphologie N.F. Suppl. 33, 118-126.

Schulte, L., 2002. Climatic and human influence on river systems and glacier fluctuations in southeast Spain since the Last Glacial Maximum. Quaternary International 93-94, 85-100.

Sheffer, N.A., Enzel, Y., Benito, G., Grodek, T., Poart, N., Lang, M., Naulet, R., Coeur, D., 2003. Historical and palaeofloods of the Ardeche river, France. Water Resources Research, 39 (12), ESG 7-1/7-13

Sheffer, N.A., Rico, M., Enzel, Y., Benito, G., Grodek, T., 2008. The palaeoflood record of the Gardon river, France: A comparison with the extreme 2002 flood event. Geomorphology 98, 71-83.

Small, A.M., Small, C., Campbell, I., Mackinnon, M., Prowse, T., Sipe, C., 1998. Field survey in the Basentello Valley on the Basilicata-Puglia border. Echos du Monde Classique/Classical Views, XLII 17, 337-371.

Snoussi, M., Haida, S., Imassi, S., 2002. Effects of the construction of dams on the water and sediment fluxes of the Moulouya and the Sebou Rivers, Morocco. Regional Environmental Change 3, 5-12.

Stein, M., Litt, T., 2013. Reply to comment by Christoph Zielhofer and Bernhard Weninger on the article: "Holocene climate variability in the Levant from the Dead Sea pollen record" by Litt et al. Quaternary Science Reviews 49 (2012) 95-105. Quaternary Science Reviews 59, 113-114.

Steinhilber, F., Beer, J., Fröhlich, C., 2009. Total solar irradiance during the Holocene. Geophysical Research Letters 36, L19704. 
Steinmann, S., Bartels, G., 1982: Quartärökologische Beobachtungen aus Nord- und Südtunesien. Catena 9, 95-108.

Stiros, S., 2009. Earthquekes. In: J. Woodward (ed.), The Physical Geography of the Mediterranean. Oxford University Press, Oxford, 469-491.

Struglia, M.V., Mariotti, A., Filograsso, A., 2004. River discharge into the Mediterranean Sea: Climatology and aspects of the observed variability. Journal of Climate 17, 4740-4751.

Thorndycraft V.R., Benito G., 2006a. Late Holocene fluvial chronology of Spain: The role of climatic variability and human impact. Catena 66 (1-2) 34-41.

Thorndycraft, V.R., Benito, G., 2006b. The Holocene fluvial chronology of Spain: evidence from a newly compiled radiocarbon database. Quaternary Science Reviews 25, 223-234.

Thorndycraft, V.R, Benito G., Rico, M., Sánchez-Moya, Y., Sopeña A., Casas, A., 2004. A Late Holocene palaeoflood record from slackwater flood deposits of the Llobregat River, NE Spain. Journal of the Geological Society of India 64, 549-559.

Thorndycraft, V.R Benito G., Rico, M., Sánchez-Moya, Y., Sopeña A., Casas, A., 2005. A long-term flood discharge record derived from slackwater flood deposits of the Llobregat River, NE Spain. Journal of Hydrology 313, 16-31.

Thornes, J., López-Bermúdez, F., Woodward, J., 2009. Hydrology, river regimes and sediment yield. In: J. Woodward (ed.), The Physical Geography of the Mediterranean. Oxford University Press, Oxford, 229-253.

Tinner, W., van Leeuwen, J.F.N., Colombaroli, D., Vescovi, E., van der Knaap, W.O., Henne, P.H., Pasta, S., D’Angelo, S., La Mantia, T., 2009. Holocene environmental and climatic changes at Gorgo Basso, a coastal lake in southern Sicily, Italy. Quaternary Science Reviews 28, 1498-1510.

Trigo, R., Xoplaki, E., Zorita, E., Luterbacher, J., Krichak, S.O., Alpert, P., Jacobeit, J., Sáenz, J., Fernández, J., González-Rouco, F., Garcia-Herrera, R., Rodó, X, Brunetti, M., Nanni, T., Maugeri, M., Türkes, M., Gimeno, L., Ribera, P., Brunet, M., Trigo, I.F., Crepón, M., Mariotti, M., 2006. Chapter 3. Relations between variability in the Mediterranean region and mid-latitude variability. Dev. Earth Environ. Sci. 4 (C), 179-226.

Trigo, R.M., Pozo-Vázquez, D., Osborn, T.J., Castro-Díez, Y., Gámiz-Fortis, S., Esteban-Parra, M.J., 2004. North Atlantic Oscillation influence on precipitation, river flow and water resources in the Iberian Peninsula. International Journal of Climatology 24, 925-944.

Trouet, V.R., Esper, J., Graham, N.E., Baker, A., Scourse, J.D., Frank, D.C., 2009. Persistent positive North Atlantic Oscillation Mode dominated the Medieval Climate Anomaly. Science 324, 78-80.

Türkeş, M., Erlat, E., 2008. Influence of the Arctic Oscillation on variability of winter mean temperatures in Turkey. Theoretical and Applied Climatology 92, 75-85.

van Geel, B., van der Plicht, J., Kilian, M. R., Klaver, E. R., Kouwenberg, J. H. M., Renssen, H., Reynaud-Farrera, I., Waterbolk, H.T., 1998. The sharp rise of $14 \mathrm{C}$ around 800 cal BC: possible causes, related climatic teleconnections and the impact on human environments, Radiocarbon 40, 535-550.

Vannière, B., Magny, M., Joannin, S., Simonneau, A., Wirth, S. B., Hamann, Y., Chapron, E., Gilli, A., Desmet, M., and Anselmetti, F.S., 2013. Orbital changes, variation in solar activity and increased anthropogenic activities: controls on the Holocene flood frequency in the Lake Ledro area, Northern Italy, Clim. Past, 9, 1193-1209.

Vaquero, J.M., 2004. Solar signals in the number of floods recorded for the Tagus river basin over the last millennium. Climatic Change 66, 23-26.

Veggiani, A., 1979. Prove di un ciclo climatico di piovosita nell'Alto Medioevo nel Cesenate. Studi Romagnoli 30, 87-101.

Veggiani, A., 1983. Degrado ambientale e dissesti idrogeologici indotti dal deterioramento climático nell'Alto medioevo in Italia: I casi riminesi. Studi Romagnoli, 34, 123-146.

Vella, C., Fleury,T.-J., Raccasi, G., Provansal, M.,Sabatier, F., Bourcier, M., 2005. Evolution of the Rhône delta plain in the Holocene. Marine Geology 222-223, 235-265.

Vella, C., Leveau, Ph., Oberin, C., Provansal, Bourcier, M., Sciallano, M., Gassend, J.M., 1998. Histoire des variations du trait de côte du golfe de Fos: cohérence chronologique fondée sur les datations radiocarbone et les datations historiques et archéologiques. Actes du colloque C14 Archéologie, Lyon, 391-396.

Vis, G.-J., Bohncke, S. J. P., Schneider, H., Kasse, C., Coenraads-Nederveen, S., Zuurbier, K., Rozema, J., 2010. Holocene flooding history of the Lower Tagus Valley (Portugal). Journal of Quaternary Science 25, 1222-1238.

Vita-Finzi, C., 1969. The Mediterranean Valleys. Cambridge University Press, Cambridge, 140 pp.

Vita-Finzi, C., 2008. Fluvial solar signals. Geological Society, London, Special Publications 296, pp. 105-115. 
Wang, Y., Lean, M.J., Sheeley, N., 2005: Modeling the Sun's Magnetic Field and Irradiance since 1713. The Astrophysical Journal, 625, 522-538. White, K., Drake, N., Millington, A., Stokes, S., 1996. Constraining the timing of alluvial fan response to Late Quaternary climatic changes, southern Tunisia. Geomorphology 17, 295-304.

Wanner, H., Solomina, O., Grosjean, M., Ritz, S., Jetel, J., 2011. Structure and origin of Holocene cold events. Quaternary Science Reviews 30, 3109-3123.

Wigley,T.M.L., Farmer, G., 1982. Climate of the eastern Mediterranean and the Near East. In JL Bintliff and W. van Zeist (eds), Palaeoclimates, Palaeoenviroments and Human Communities in the Eastern Mediterranean Region in Late Prehistory, Oxford, 3-37.

Wilhelm, B., Arnaud, F., Sabatier, P., Crouzet, C., Brisset, E., Chaumillon, E., Disnar, J.-R., Guiter, F., Malet, E., Reyss, J.-L., Tachikawa, K., Bard, E., Delannoy, J.-J., 2012. 1400 years of extreme precipitation patterns over the Mediterranean French Alps and possible forcing mechanisms. Quaternary Research 78, 1-12.

Wolf, D., Seim, A., Diaz del Olmo, F., Faust, D., 2013a. Late Quaternary fluvial dynamics of the Jarama River in central Spain. Quaternary International 302, 20-41.

Wolf, D., Seim, A., Faust, D., 2013b. Fluvial system response to external forcing and human impact Late Pleistocene and Holocene fluvial dynamics of the lower Guadalete River in western Andalucía (Spain). Boreas. doi: 10.1111/bor.12044.

Xoplaki, E., 2002. Climate variability over the Mediterranean. PhD thesis, University of Bern, Switzerland.

Xoplaki, E., González-Rouco, F., Luterbacher, J., Wanner, H., 2004. Wet season Mediterranean precipitation variability: influence of large-scale dynamics and trends. Climate Dynamics 23, 63-78.

Y1l, E.-I., Pérez-Obiol, R., Pantaleon-Cano, J., Roure, J.-M., 1997. Palynological evidence for climatic change and human activity during the Holocene on Minorca (Balearic Islands). Quaternary Research 48, 339-347.

Zacharias, N., Bassiakos, Y., Hayden, B., Theodorakopoulou, K., Michael, C.T., 2009. Luminescence dating of deltaic deposits from Eastern Crete, Greece: Geoarchaeological implications. Geomorphology, 109, 46-53.

Zerai, K., 2009. Chronostratigraphy of Holocene alluvial archives in the Wadi Sbeïtla basin (central Tunisia). Géomorphologie: relief, processus, environnement 2009/4, 271-286.

Zielhofer, C. 2006: Die römische Landnutzung und deren Einfluss auf die antike Umwelt in Nordtunesien. Geographische Rundschau 58/4, 22-29.

Zielhofer, C, Clare, L., Rollefson, G., Wächter, S., Hoffmeister, D., Bareth, G., Roettig, C., Bullmann, H., Schneider, B., Berke, H., Weninger, B., 2012. The decline of the early Neolithic population center of 'Ain Ghazal and corresponding earth-surface processes, Jordan Rift Valley. Quaternary Research 78, 427-441.

Zielhofer, C. Faust, D., 2008. Mid- and Late Holocene fluvial chronology of Tunisia. Quaternary Science Reviews 27, 580-588.

Zielhofer, C., Bussmann, J., Ibouhouten, H., Fenech, K., 2010. Flood frequencies reveal Holocene rapid climate changes (Lower Moulouya River, northeastern Morocco). Journal of Quaternary Science 25, 700-714.

Zielhofer, C., Faust, D., Baena, R., Diaz del Olmo, F., Kadereit, A., Moldenhauer, K.-M., Porras, A., 2004. Centennial-scale late Pleistocene to mid-Holocene synthetic profile of the Medjerda floodplain (Northern Tunisia). The Holocene 14, 851-861.

Zielhofer, C., Faust, D., Diaz del Olmo, F., Baena, R., 2002. Sedimentation and soil formation phases in the Ghardimaou Basin (Northern Tunisia) during the Holocene. Quaternary International 93-94, 109-125.

Zielhofer, C., Faust, D., Linstädter, J., 2008. Late Pleistocene and Holocene alluvial archives in the Southwestern Mediterranean: Changes in fluvial dynamics and past human response. Quaternary International 181, 29-54.

Zielhofer, C., Recio Espejo, J.M., Nunez Granadoz, M.A., Faust, D., 2009: Durations of soil formation and soil development indices in a Holocene Mediterranean floodplain. Quaternary International 209, 44-65.

Zorita, E., Trigo, R., Krichak, S.O., Jacobeit, J., Saenz, J., Gonzalez-Rouco, F., Rodo, X., 2004. Relationships between climate variability in the Mediterranean region and Mid-latitude variability. White Paper on Mediterranean Climate Variability and Predictability. March 2004. International CLIVAR Project Office. pp. 51-59. 
Tables

\begin{tabular}{|c|c|c|c|c|c|}
\hline No. & Site name & Type & $\begin{array}{l}\begin{array}{l}\text { No. } \\
\text { Dates } \\
\text { (n) }\end{array} \\
\end{array}$ & $\begin{array}{l}\text { Dating } \\
\text { method }\end{array}$ & Reference \\
\hline 1 & Huebra & SWDs & 24 & ${ }^{14} \mathrm{C}$ & Unpublished \\
\hline 2 & Tagus & SWD & 13 & ${ }^{14} \mathrm{C}$ & Benito et al., 2003a \\
\hline 3 & Tagus & SWD & 3 & ${ }^{14} \mathrm{C}$ & Benito et al., 2003a \\
\hline 4 & Tagus & Floodplain & 5 & ${ }^{14} \mathrm{C}$ & Vis et al., 2010 \\
\hline 5 & Guadiana & SWDs & 8 & ${ }^{14} \mathrm{C}$ & Ortega and Garzón, 2003, 2009 \\
\hline 6 & Guadalete & Floodplain & 3 & ${ }^{14} \mathrm{C}$ & Wolf et al., 2013 \\
\hline 7 & Guadalhorce & SWD & 7 & ${ }^{14} \mathrm{C}$ & Unpublished \\
\hline 8 & Guadalentin & SWD & 14 & ${ }^{14} \mathrm{C}$ & Benito et al., 2010 \\
\hline 9 & Segura River & SWD & 3 & ${ }^{14} \mathrm{C}$ & Garcia-Garcia et al., 2013 \\
\hline 10 & Turia River & Floodplain & 4 & ${ }^{14} \mathrm{C}$ & $\begin{array}{l}\text { Carmona et al., } 1994 \\
\text { Carmona and Ruiz, } 2011\end{array}$ \\
\hline 11 & Rambla de la Viuda & SWD & 2 & ${ }^{14} \mathrm{C}$ & Machado et al., 2012 \\
\hline 12 & Llobregat River & SWD & 5 & ${ }^{14} \mathrm{C}$ & Thorndycraft et al., 2004, 2005 \\
\hline 13 & Segre River & SWD & 3 & ${ }^{14} \mathrm{C}$ & Rico 2004 \\
\hline 14 & Regallo River & Floodplain & 1 & ${ }^{14} \mathrm{C}$ & Macklin et al., 1994 \\
\hline 15 & Bergantes River & SWDs & 2 & IRSL & López-Avilés et al., 1998 \\
\hline 16 & Gardon & SWDs & 9 & ${ }^{14} \mathrm{C}$ & Sheffer et al., 2006 \\
\hline 17 & Ardeche & SWD & $\begin{array}{l}7 \\
6\end{array}$ & $\begin{array}{l}{ }^{14} \mathrm{C} \\
\mathrm{OSL}\end{array}$ & Sheffer et al, 2003 \\
\hline 18 & Rhone R., at Citelle & Floodplain & 7 & ${ }^{14} \mathrm{C}$ & Berger et al., 2002 \\
\hline 19 & Rhone R. at Castelet & Floodplain & 5 & ${ }^{14} \mathrm{C}$ & Bruenton et al., 2001 \\
\hline 20 & Ubaye R., at L'Abéous & Floodplain & 4 & ${ }^{14} \mathrm{C}$ & Provansal et al., 2002 \\
\hline 21 & Bléone R., Baume & Floodplain & 2 & ${ }^{14} \mathrm{C}$ & Provansal et al., 2002 \\
\hline 22 & Rhone delta, at Calade & Delta plain & 2 & ${ }^{14} \mathrm{C}$ & Bruenton et al., 2001 \\
\hline 23 & Rhone delta, at Arles & Delta plain & 2 & ${ }^{14} \mathrm{C}$ & Bruenton et al., 2001 \\
\hline 24 & $\begin{array}{l}\text { Rhone delta, at le } \\
\text { Carrelet }\end{array}$ & Delta plain & 2 & ${ }^{14} \mathrm{C}$ & Arnaud-Fassetta, 2002 \\
\hline 25 & $\begin{array}{l}\text { Rhone delta, at } \\
\text { Combettes }\end{array}$ & Delta plain & 1 & ${ }^{14} \mathrm{C}$ & Arnaud-Fassetta, 2002 \\
\hline 26 & Bradano River & Floodplain & 13 & ${ }^{14} \mathrm{C}$ & $\begin{array}{l}\text { Piccarreta et al., } 2011 \\
\text { Neboit, } 1984 \\
\text { Brückner, } 1986 \\
\text { Abbott and Valastro, } 1995 \\
\text { Cotecchia et al., 1969 } \\
\text { Small et al. (1998) }\end{array}$ \\
\hline 27 & Basento River & Floodplain & 18 & ${ }^{14} \mathrm{C}$ & $\begin{array}{l}\text { Piccarreta et al., } 2011 \\
\text { Boenzi et al. } 2008 \\
\text { Neboit, } 1983 \\
\text { Abbott and Valastro, } 1995\end{array}$ \\
\hline 28 & Cavone River & Floodplain & 4 & ${ }^{14} \mathrm{C}$ & $\begin{array}{l}\text { Piccarreta et al., } 2011 \\
\text { Neboit, 1983, } 1984 \\
\text { Brückner, 1983 }\end{array}$ \\
\hline 29 & Osum River & Floodplain & 1 & ${ }^{14} \mathrm{C}$ & Carcaillet et al. 2009 \\
\hline 30 & $\begin{array}{l}\text { Vjoje (Voidomatis) } \\
\text { River }\end{array}$ & Floodplain & 1 & ${ }^{14} \mathrm{C}$ & Carcaillet et al. 2009 \\
\hline 31 & Kerynitis River & Channel bed & $7(0)$ & ${ }^{14} \mathrm{C}$ & Pavlides et al., 2004; Koukouvelas et al., 2001 \\
\hline 32 & Evrotas & Floodplain & 1 & OSL & Pope and Wilkinson, 2006 \\
\hline 33 & Evrotas & Floodplain & 1 & OSL & Pope and Wilkinson, 2006 \\
\hline 34 & River Asopos & Floodplain & $\begin{array}{l}5 \\
11 \\
\end{array}$ & $\begin{array}{l}{ }^{14} \mathrm{C} \\
\mathrm{OSL}\end{array}$ & $\begin{array}{l}\text { Fuchs and Wagner, 2005; Fuchs and Wagner, } \\
\text { 2003; Fuchs and Lang, 2001 }\end{array}$ \\
\hline 35 & Angithis River & Floodplain & 2 & ${ }^{14} \mathrm{C}$ & Lespez, 2003 \\
\hline 36 & Stomiou & Floodplain & 5 & OSL & Booth, 2010 \\
\hline 37 & Mavros & Floodplain & 1 & OSL & Booth, 2010 \\
\hline 38 & Rapanas & $\begin{array}{l}\text { Floodplain } \\
\text { palaeochannel }\end{array}$ & 3 & OSL & Booth, 2010 \\
\hline 39 & Klados & SWDs & $1(0)$ & ${ }^{14} \mathrm{C}$ & Booth, 2010 \\
\hline 40 & Heroktena & Floodplain & 5 & OSL & Booth, 2010 \\
\hline 41 & Anapodiaris & Floodplain & 11 & OSL & Noble, 2004 \\
\hline 42 & River Istron & Floodplain & 7 & OSL & Zacharias et al., 2009 \\
\hline 43 & Ezousas & Floodplain & 2 & OSL & Deckers, 2005 \\
\hline 44 & River Deli & Floodplain & 5 & ${ }^{14} \mathrm{C}$ & Beach and Luzzadder-Beach, 2008 \\
\hline 45 & Orontes River & Floodplain & 1 & ${ }^{14} \mathrm{C}$ & Casana, 2008 \\
\hline 46 & Nahal Zin & SWDs & 5 & ${ }^{14} \mathrm{C}$ & Greenbaum et al. 2000 \\
\hline 47 & Nahal Resisim & Floodplain & 1 & ${ }^{14} \mathrm{C}$ & Goldberg, 1984 \\
\hline 48 & Wadi el-Qudeirat & Floodplain & 3 & ${ }^{14} \mathrm{C}$ & Goldberg, 1984 \\
\hline 49 & $\begin{array}{l}\text { Mid-Medjerda } \\
\text { catchment }\end{array}$ & Floodplain & $\begin{array}{l}\text { A: } 0 \\
\text { S: } 10\end{array}$ & ${ }^{14} \mathrm{C}$ & Scharpenseel and Zarkosek 1979 \\
\hline 49 & Mid-Medjerda & Floodplain & A: 0 & ${ }^{14} \mathrm{C}$ & Scharpenseel and Schiffmann 1985 \\
\hline
\end{tabular}




\begin{tabular}{|c|c|c|c|c|c|}
\hline & catchment & & S: 26 & & \\
\hline 49 & $\begin{array}{l}\text { Mid-Medjerda } \\
\text { catchment }\end{array}$ & Floodplain & $\begin{array}{l}\text { A: } 42 \\
\text { S: } 13\end{array}$ & ${ }^{14} \mathrm{C}$ & $\begin{array}{l}\text { Faust et al. } 2004 \\
\text { Zielhofer et al. } 2004 \\
\text { Zielhofer et al. } 2008 \\
\text { Zielhofer and Faust } 2008\end{array}$ \\
\hline 50 & Siliana R. & Floodplain & $\begin{array}{l}\text { A: } 6 \\
\text { S: } 1\end{array}$ & ${ }^{14} \mathrm{C}$ & Steinmann and Bartels 1982 \\
\hline 51 & Miliane R. & Floodplain & $\begin{array}{l}\text { A: } 0 \\
\text { S: } 4\end{array}$ & ${ }^{14} \mathrm{C}$ & Scharpenseel and Schiffmann 1985 \\
\hline 52 & Cap Bon & Fluvial deposits & $\begin{array}{l}\text { A: } 0 \\
\text { S: } 3\end{array}$ & ${ }^{14} \mathrm{C}$ & Scharpenseel and Schiffmann 1985 \\
\hline 52 & Cap Bon & $\begin{array}{l}\text { Floodplain and } \\
\text { fluvial deposits }\end{array}$ & $\begin{array}{l}\text { A: } 6 \\
\text { S: } 1\end{array}$ & ${ }^{14} \mathrm{C}$ & $\begin{array}{l}\text { Bartels and Steinmann } 1980 \\
\text { Steinmann and Bartels } 1982\end{array}$ \\
\hline 53 & Ain Djelloula R. & Floodplain & $\begin{array}{l}\text { A: } 1 \\
\text { S: } 0\end{array}$ & ${ }^{14} \mathrm{C}$ & Steinmann and Bartels 1982 \\
\hline 54 & Hatab catchment & Floodplain & $\begin{array}{l}\text { A: } 0 \\
\text { S: } 8\end{array}$ & ${ }^{14} \mathrm{C}$ & Scharpenseel and Schiffmann 1985 \\
\hline 55 & Sbeitla catchment & Floodplain & $\begin{array}{l}\text { A: } 2 \\
\text { S: } 2\end{array}$ & ${ }^{14} \mathrm{C}$ & Zerai 2009 \\
\hline 55 & Sbeitla catchment & $\begin{array}{l}\text { Floodplain and } \\
\text { slopes }\end{array}$ & $\begin{array}{l}\text { A: } 7 \\
\text { S: } 27\end{array}$ & ${ }^{14} \mathrm{C}$ & Scharpenseel and Schiffmann 1985 \\
\hline 56 & Ksour Essaf & Fluvial deposits & $\begin{array}{l}\text { A: } 0 \\
\text { S: } 1\end{array}$ & ${ }^{14} \mathrm{C}$ & Scharpenseel and Schiffmann 1985 \\
\hline 57 & $\begin{array}{l}\text { Eastern Maghreb } \\
\text { Saharan margin: } \\
\text { - Kasserien R. } \\
\text { - Es Sgniffa R. } \\
\text { - Chéria- } \\
\text { Mezeraa R. } \\
\end{array}$ & Floodplain & $\begin{array}{l}\text { A: } 9 \\
\text { S: } 2\end{array}$ & ${ }^{14} \mathrm{C}$ & Ballais, 1995 \\
\hline 57 & $\begin{array}{l}\text { Eastern Maghreb } \\
\text { Saharan margin } \\
\text { - Nefta (Oued) } \\
\text { - El Rharsa } \\
\end{array}$ & $\begin{array}{l}\text { Floodplain and } \\
\text { chott }\end{array}$ & $\begin{array}{l}\text { A: } 0 \\
\text { S: } 6\end{array}$ & ${ }^{14} \mathrm{C}$ & Scharpenseel and Schiffmann 1985 \\
\hline 58 & Melah R. & Floodplain & $\begin{array}{l}\text { A: } 0 \\
\text { S: } 10\end{array}$ & ${ }^{14} \mathrm{C}$ & Scharpenseel and Schiffmann, 1985 \\
\hline 59 & $\begin{array}{l}\text { Ersifa and Lakarit } \\
\text { catchments }\end{array}$ & Floodplain & $\begin{array}{l}\text { A: } 0 \\
\text { S: } 5 \\
\end{array}$ & ${ }^{14} \mathrm{C}$ & Scharpenseel and Schiffmann 1985 \\
\hline 59 & El M’Dou R. & Floodplain & $\begin{array}{l}\text { A: } 0 \\
\text { S: } 2 \\
\end{array}$ & ${ }^{14} \mathrm{C}$ & Steinmann and Bartels 1982 \\
\hline 60 & Tataouine catchment & Floodplain & $\begin{array}{l}\text { A: } 0 \\
\text { S: } 4 \\
\end{array}$ & ${ }^{14} \mathrm{C}$ & Scharpenseel and Schiffmann 1985 \\
\hline 61 & Moulouya River & Floodplain & $\begin{array}{l}\mathrm{A}: 14 \\
\mathrm{~S}: 15\end{array}$ & ${ }^{14} \mathrm{C}$ & $\begin{array}{l}\text { Zielhofer et al. } 2010 \\
\text { Ibouhouten et al. } 2010 \\
\text { Linstädter and Zielhofer } 2010\end{array}$ \\
\hline 62 & Kert River & Floodplain & $\begin{array}{l}\text { A: } 11 \\
\text { S: } 0 \\
\end{array}$ & ${ }^{14} \mathrm{C}$ & $\begin{array}{l}\text { El Amrani et al. } 2008 \\
\text { Zielhofer et al. } 2008\end{array}$ \\
\hline 63 & Lake Zóñar & Lake & - & & Martín-Puertas et al., 2009 \\
\hline 64 & Lake Siles & Lake & - & & Carrión, 2002 \\
\hline 65 & Lake Taravilla & Lake & - & & Moreno et al., 2008 \\
\hline 66 & Lake Estanya & Lake & - & & Morellón et al., 2008 \\
\hline 67 & Lake Montcortès & Lake & - & & Corella et al., 2014 \\
\hline 68 & Lake Cerin; & Lake & - & & Magny, 2004 \\
\hline 69 & Lake Ledro & Lake & - & & Vannière et al., 2013 \\
\hline 70 & Lake Accesa & Lake & - & & Magny et al., 2007; 2009 \\
\hline 71 & Lake Fucino & Lake & - & & Giraudi, 1998 \\
\hline 72 & Lake Preola & Lake & - & & Magny et al., 2011; \\
\hline 73 & Maliq, Albania & Lake & - & & Magny et al., 2009 \\
\hline 74 & Dead Sea & Lake & - & & $\begin{array}{l}\text { Enzel et al., 2003Bookman et al., 2004, 2006; } \\
\text { Migowski et al. } 2006\end{array}$ \\
\hline
\end{tabular}

Table 1. Location of sites included in Figure 1 with bibliographic references, and number of radiocarbon dates used to produce cumulative probability density plots. A: Dates in sedimentary environments indicating fluvial activity. S: Dates on pedogenetic horizons indicating stability conditions. 


\begin{tabular}{|c|c|c|c|c|c|c|c|}
\hline $\begin{array}{c}\text { W-Iberian } \\
\text { Peninsula } \\
\text { (cal. yr } \\
\text { B.P.) }\end{array}$ & $\begin{array}{c}\text { E-Iberian } \\
\text { Peninsula } \\
\text { (cal. yr } \\
\text { B.P.) }\end{array}$ & $\begin{array}{l}\text { Southern } \\
\text { France } \\
\text { (cal. yr } \\
\text { B.P.) }\end{array}$ & $\begin{array}{c}\text { NE- } \\
\text { Morocco } \\
\text { (cal. yr } \\
\text { B.P.) }\end{array}$ & $\begin{array}{l}\text { Southern } \\
\text { Italy } \\
\text { (cal. yr } \\
\text { B.P.) }\end{array}$ & $\begin{array}{l}\text { Tunisia } \\
\text { (cal. yr } \\
\text { B.P.) }\end{array}$ & $\begin{array}{c}\text { Eastern } \\
\text { Mediterranean } \\
\text { (cal. yr B.P.) }\end{array}$ & $\begin{array}{c}\text { Overlapping } \\
\text { (cal. yr B.P.) } \\
\text { (No. of } \\
\text { regions) }\end{array}$ \\
\hline \multicolumn{8}{|l|}{$9500-9200$} \\
\hline & & & $8900-8700$ & & & & \\
\hline & & $7800-7150$ & & $7400-6750$ & $\begin{array}{l}7600- \\
7150\end{array}$ & $7800-7150$ & $\begin{array}{c}7400-7150 \\
\text { (4) }\end{array}$ \\
\hline & & & & & $\begin{array}{l}6200- \\
6000\end{array}$ & & \\
\hline \multirow[t]{3}{*}{$4800-4500$} & $4850-4700$ & $4800-4500$ & & $4800-4600$ & $\begin{array}{c}4800- \\
4500\end{array}$ & & $\begin{array}{c}4800-4600 \\
(5)\end{array}$ \\
\hline & & & $4200-3500$ & $4200-4100$ & $\begin{array}{c}4100- \\
3700\end{array}$ & $4100-3700$ & $\begin{array}{c}4100-3700 \\
\text { (3) }\end{array}$ \\
\hline & & & $3300-3100$ & $3450-3000$ & $\begin{array}{l}3300- \\
3000\end{array}$ & $3400-3200$ & $\begin{array}{c}3300-3200 \\
(4)\end{array}$ \\
\hline \multirow[t]{5}{*}{$2850-2250$} & $2850-2700$ & $3000-2750$ & & & $\begin{array}{l}2850- \\
2350\end{array}$ & & $\begin{array}{c}2850-2750 \\
\text { (4) }\end{array}$ \\
\hline & $2450-2150$ & $2300-1750$ & $2500-2100$ & $\begin{array}{l}2350- \\
1850\end{array}$ & & & $\begin{array}{c}2300-2100 \\
\text { (4) }\end{array}$ \\
\hline & & & & $1700-1600$ & & $1900-1600$ & $\begin{array}{c}1700-1600 \\
\text { (2) }\end{array}$ \\
\hline & & $1500-1350$ & & $1500-1400$ & $\begin{array}{l}1600- \\
1300\end{array}$ & & $\begin{array}{c}1500-1400 \\
\text { (3) }\end{array}$ \\
\hline & & & & & & $1200-1100$ & \\
\hline \multirow[t]{2}{*}{$1100-800$} & $1050-800$ & $950-800$ & & $1050-800$ & $900-800$ & & $950-800(3)$ \\
\hline & & & & & $700-500$ & $900-600$ & \\
\hline \multirow[t]{2}{*}{$500-150$} & $600-150$ & $600-400$ & & & $300-200$ & & $\sim 300(3)$ \\
\hline & & $250-100$ & & $200-100$ & & $250-85$ & $200-100(3)$ \\
\hline
\end{tabular}

Table 2. Centennial and multi-centennial episodes of flooding in Mediterranean regions based on analysis of ${ }^{14} \mathrm{c}$-dated Holocene fluvial units. Note: Overlapping episodes are indicated in the right column with the number of regions with common periods indicated in brackets . cal.-calibrated

\begin{tabular}{|c|c|c|c|c|c|c|c|}
\hline \multirow[b]{2}{*}{ Region } & \multicolumn{7}{|c|}{ Proximity Matrix (Jaccard's Measure) } \\
\hline & $\begin{array}{l}\text { West- } \\
\text { Iberia }\end{array}$ & E-Iberia & $\begin{array}{c}\mathrm{S} \\
\text { France } \\
\end{array}$ & $\begin{array}{c}\text { Morocco } \\
(\mathrm{NE})\end{array}$ & S Italy & Tunisia & $\begin{array}{l}\text { Eastern } \\
\text { Mediter }\end{array}$ \\
\hline W-Iberia & 1.00 & 0.56 & 0.28 & 0.08 & 0.15 & 0.33 & 0.04 \\
\hline E-Iberia & 0.56 & 1.00 & 0.36 & 0.16 & 0.18 & 0.23 & 0.03 \\
\hline Southern France & 0.28 & 0.36 & 1.00 & 0.10 & 0.32 & 0.27 & 0.13 \\
\hline Morocco (NE) & 0.08 & 0.16 & 0.10 & 1.00 & 0.28 & 0.32 & 0.21 \\
\hline Southern Italy & 0.15 & 0.18 & 0.32 & 0.28 & 1.00 & 0.28 & 0.18 \\
\hline Tunisia & 0.33 & 0.23 & 0.27 & 0.32 & 0.28 & 1.00 & 0.31 \\
\hline E. Mediterranean & 0.04 & 0.03 & 0.13 & 0.21 & 0.18 & 0.31 & 1.00 \\
\hline
\end{tabular}

Table 3. Proximity matrix based on Jaccard's similarity coefficient. The highest similarity value equals 1. The variable data sets include the last 5000-yr record for the seven regional datasets with binary information of temporal flood activity in 100-yr bins. Classes: 1: Flood activity 100-yr bins; 0: Nonactivity 100 -yr bins. Percentage of class 1 values in datasets. W Iberia 25.5\%; E Iberia 27.5\%; S France 37.3\%; Morocco 27.5\%; S Italy 35.3\%, Tunísia 45.1\%; E Mediterranean 29.4\%. Correlation values larger than 0.20 are printed in bold 


\begin{tabular}{|l|r|r|c|}
\hline \multicolumn{3}{|c|}{ Component Matrix } \\
\hline \multicolumn{1}{|c|}{ Component } & \multicolumn{1}{|c|}{1} & \multicolumn{1}{c|}{2} & \multicolumn{1}{c|}{3} \\
\hline \% of Variance explained & 28.9 & 19.8 & 16.3 \\
\hline E-Iberian Penin & 0.82 & & \\
W-Iberian Penin & 0.81 & 0.20 & -0.33 \\
Eastern Mediterranean & -0.56 & 0.28 & -0.21 \\
Southern France & 0.54 & & 0.49 \\
Tunisia & & 0.79 & -0.33 \\
Morocco & -0.26 & 0.67 & \\
Southern Italy & & 0.43 & 0.79 \\
\hline
\end{tabular}

Table 4. Three component matrix accounting for up to $65 \%$ of total variance extracted from Principal Component Analysis. Note the first component explained by positive sign of Iberian and southern France records and negative correlation of eastern Mediterranean. 